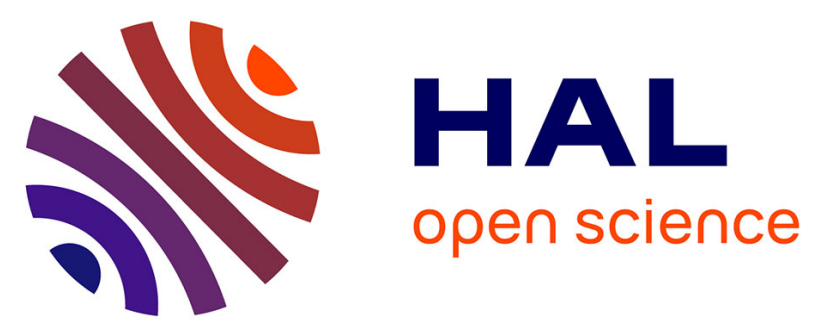

\title{
Palaeozoic oolitic ironstone of the French Armorican Massif: a chemical and structural trap for orogenic base metal-As-Sb-Au mineralization during Hercynian strike-slip deformation.
}

Eric Gloaguen, Yannick Branquet, Philippe Boulvais, Y. Moëlo, Jean-Jacques

Chauvel, P.J. Chiappero, Eric Marcoux

\section{To cite this version:}

Eric Gloaguen, Yannick Branquet, Philippe Boulvais, Y. Moëlo, Jean-Jacques Chauvel, et al.. Palaeozoic oolitic ironstone of the French Armorican Massif: a chemical and structural trap for orogenic base metal-As-Sb-Au mineralization during Hercynian strike-slip deformation.. Mineralium Deposita, 2007, 42, pp.4, 399-422. 10.1007/s00126-006-0120-4 . hal-00107971

\section{HAL Id: hal-00107971 \\ https://hal-insu.archives-ouvertes.fr/hal-00107971}

Submitted on 19 Mar 2007

HAL is a multi-disciplinary open access archive for the deposit and dissemination of scientific research documents, whether they are published or not. The documents may come from teaching and research institutions in France or abroad, or from public or private research centers.
L'archive ouverte pluridisciplinaire HAL, est destinée au dépôt et à la diffusion de documents scientifiques de niveau recherche, publiés ou non, émanant des établissements d'enseignement et de recherche français ou étrangers, des laboratoires publics ou privés. 


\title{
Palaeozoic oolitic ironstone of the French Armorican Massif: a chemical and structural trap for orogenic base metal-As-Sb-Au mineralisation during Hercynian strike-slip deformation
}

Eric Gloaguen ${ }^{1,} 5$, Yannick Branquet ${ }^{1}, \quad$ Philippe Boulvais ${ }^{2}, \quad$ Yves Moëlo $^{3}$, JeanJacques Chauvel $^{2}$, Pierre-Jacques Chiappero ${ }^{4}$ and Eric Marcoux ${ }^{1}$

(1) Institut des Sciences de la Terre d'Orléans (ISTO), UMR 6113 CNRS/Université d'Orléans, Bâtiment Géosciences, rue de Saint Amand, BP 6759, 45067 Orleans Cedex 2, France

(2) Géosciences Rennes, UMR 6118, CNRS/Université de Rennes 1, 35042 Rennes Cedex, France

(3) Laboratoire de Chimie du Solide, Institut des Matériaux Jean Rouxel, CNRS UMR 6502, 2, rue de la Houssinière, BP 32229, 44322 Nantes Cedex 3, France

(4) Département Histoire de la Terre, USM 201-UMR 7160, Muséum National d'Histoire Naturelle, 61 rue Buffon, 75005 Paris, France

(5) Present address: BRGM, 3, avenue Claude-Guillemin, BP6009, 45060 Orleans Cedex 2, France

\begin{abstract}
In the Saint-Aubin-des-Châteaux quarry (Armorican Hercynian belt, western France), an epigenetic hydrothermal alteration affects an oolitic ironstone layer intercalated within the Lower Ordovician Grès armoricain Formation. The hydrothermal overprint produced pervasive and massive sulphidation with stratoid pyritised lenticular bodies within the oolitic ironstone layer. These sulphide lenses are spatially associated with strike-slip faults and extend laterally from them. After the massive sulphidation stage ( $\mathrm{Fe}-\mathrm{As}$, stage 1), subsequent fracturing allowed the deposition of base metals (stage 2) and $\mathrm{Pb}-\mathrm{Sb}-\mathrm{Au}$ (stage 3) parageneses in veins. The dominant brittle structures are vertical extension veins, conjugate shear veins and strike-slip faults of various orders. All these structures are filled with the same paragenetic sequence. Deformation analysis allows the identification of structures that developed incrementally via right-lateral simple shear compatible with bulk strain affecting the Central Armorican Domain. Each increment corresponds to a fracture set filled with specific parageneses. Successive hydrothermal pulses reflect clockwise rotation of the horizontal shortening direction. Geothermometry on chlorite and arsenopyrite shows an input of hot hydrothermal fluids (maximum of $390-350^{\circ} \mathrm{C}$ ) during the main sulphide stage 1 . The subsequent stages present a marked temperature drop $\left(300-275^{\circ} \mathrm{C}\right)$. Lead isotopes suggest that the lead source is similar for all hydrothermal stages and corresponds to the underlying Neo-Proterozoic basement. Lead isotope data, relative ages of deformation and comparison with neighbouring deposits suggest that large-scale fluid pulses occurred during the whole Hercynian orogeny rather than pulses restricted to the late Hercynian period. The vicinity of the Hercynian internal domain appears as a key control for deformation and fluid flow in the oolitic ironstones, which acted as a chemical and structural trap for the hydrothermal fluids. The epigenetic mineralisation of Saint-Aubin-des-Châteaux appears to be very similar to epigenetic sulphidation described in banded iron formation-hosted gold deposits.
\end{abstract}

Keywords : Oolitic ironstone - Orogenic gold - Lead isotopes - France 


\section{Introduction}

Iron-rich sedimentary rocks ( $>15 \% \mathrm{Fe})$ have two main types: (1) banded iron formations (BIFs) of Precambrian age and (2) ironstones, which are mostly oolitic and with an age ranging from Late Precambrian to Tertiary (see reviews by Gross 1996a; Christie and Brathwaite 1997 for details and sub-types). BIFs host important Au deposits, commonly associated with strong sulphidation (massive replacement of oxides and/or in veins) and hydrothermal alteration (e.g. Foster and Gilligan 1987; Thompson et al. 1990; Ledru and Bouchot 1993; Newton et al. 1997; McCuaig and Kerrich 1998). The syngenetic, with remobilisation or not, vs epigenetic origin of BIF-hosted gold deposits is still debated, but the geochemical and rheological controls of Au mineralisation in BIFs are now well established (Fripp 1976; Kerrich and Fryer 1979; Phillips et al. 1984; Groves and Vearcombes 1990; Macdonald 1990; Ledru and Bouchot 1993). In contrast, syngenetic and epigenetic sulphidation of oolitic ironstones is not well documented. In oolitic ironstone formations (e.g. Palaeozoic ironstones like Clinton-USA, Wabana-Canada, Coal Measures-UK), only depositional and diagenetic sulphides, particularly framboidal pyrite, are reported, reflecting sulphate availability and organic carbon content in the environment (Lyons 1957; Spears and Caswell 1986; Spears 1989; Cotter and Link 1993; Gross 1996b). One may thus question why oolitic ironstones, in contrast to BIFs, are apparently less affected by sulphidation or polymetallic mineralisation processes. A key observation is that, on the contrary to Aubearing Precambrian BIFs, the oolitic ironstones (e.g. the Lorraine-Luxembourg so-called Minette in the Paris basin and Clinton ironstones in the Appalachian foreland basin) are located far from orogenic internal zones where deformation, magmatism and metamorphism enhance fluid flow and metal transport. In this study, we present structural, petrological and geochemical data on the hydrothermal alteration and the polymetallic epigenetic mineralisation that developed in the Lower Ordovician oolitic ironstone of the Saint-Aubindes-Châteaux area, Armorican Massif, Hercynian belt of western France.

\section{Geological setting}

The Saint-Aubin-des-Châteaux aggregate quarry is located in the Central Armorican Domain (CAD), about $6 \mathrm{~km}$ north from the Northern Branch of the South Armorican Shear Zone (NBSASZ, Figs. 1a,b and 2a). The NBSASZ and the North Armorican Shear Zone, which bound the CAD, are the main structures of the Hercynian Armorican Massif and correspond to Middle to Late Carboniferous right-lateral wrenching (Jégouzo 1980; Cartier 2002; Gumiaux 2003). The CAD is mostly composed of a Neo-Proterozoic pelitic basement covered by Palaeozoic detrital sediments that underwent deformation and anchizonal-greenschist metamorphism during the Carboniferous (Le Corre et al. 1991). 


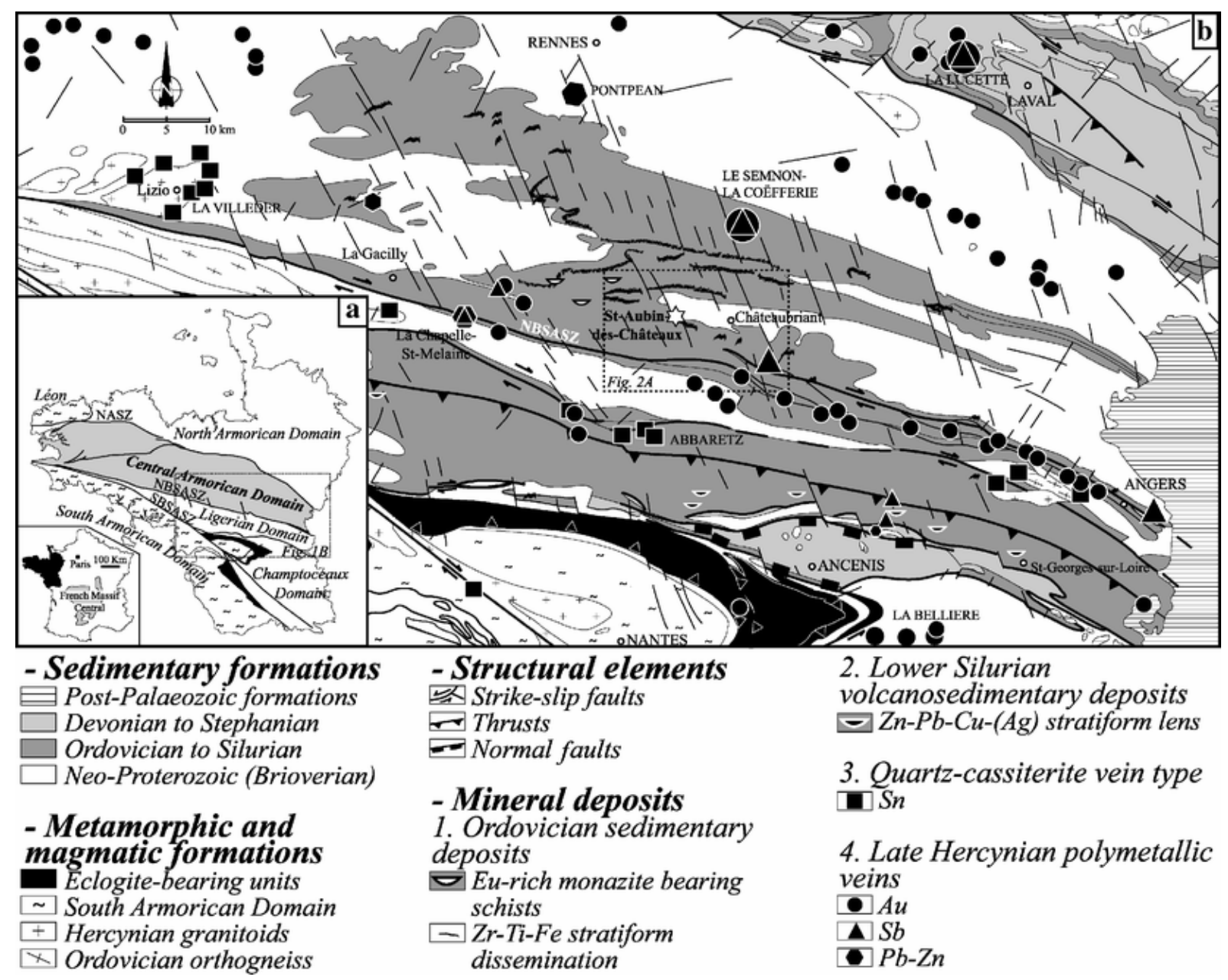

Fig. 1 a Sketch map of the main structural domains of the Armorican Massif. b Geological map of the Eastern central part of the Armorican Massif, modified from Chantraine et al. (1996). Mineral deposits from Méloux et al. (1979). Note the strong spatial relation between Hercynian granites and tin deposits (i.e. La Villeder) and between Late Hercynian shear zones and some gold deposits

\section{Palaeozoic sedimentation}

Lower Ordovician sandstones overlie unconformably the Neo-Proterozoic basement (Fig. 2b). The so-called Grès armoricain Formation, of Arenig age, records an important marine transgression (Guillocheau and Rolet 1982; Durand and Noblet 1986). The formation includes three members (Kerforne 1915; Chauvel 1971), which are from bottom to top (Fig. 2b): (1) the lower member made of thick sandstone layers with fine mudstone intercalations; (2) the intermediate member made of sandstone, siltstone and mudstone alternations and (3) the upper member made of thinner micaceous sandstone layers with mudstone intercalations. The Ordovician conditions of sedimentation are characterised by a nearshore depositional environment with storm effects in a domain of internal platform protected by barriers (Chauvel and Le Corre 1971; Guillocheau and Rolet 1982; Joseph 1982). Oolitic ironstones form sand-infratidal media, on the top of transgressive sequences during a period of sedimentary stabilisation (Joseph 1982). The marine conditions of sedimentation prevailed up to the Middle Devonian. Wrenching, along master shear zones bordering the CAD, induced the location of Upper Devonian to Stephanian marine depocentres within individualised longitudinal basins (e.g. Laval basin, Fig. 1b). 


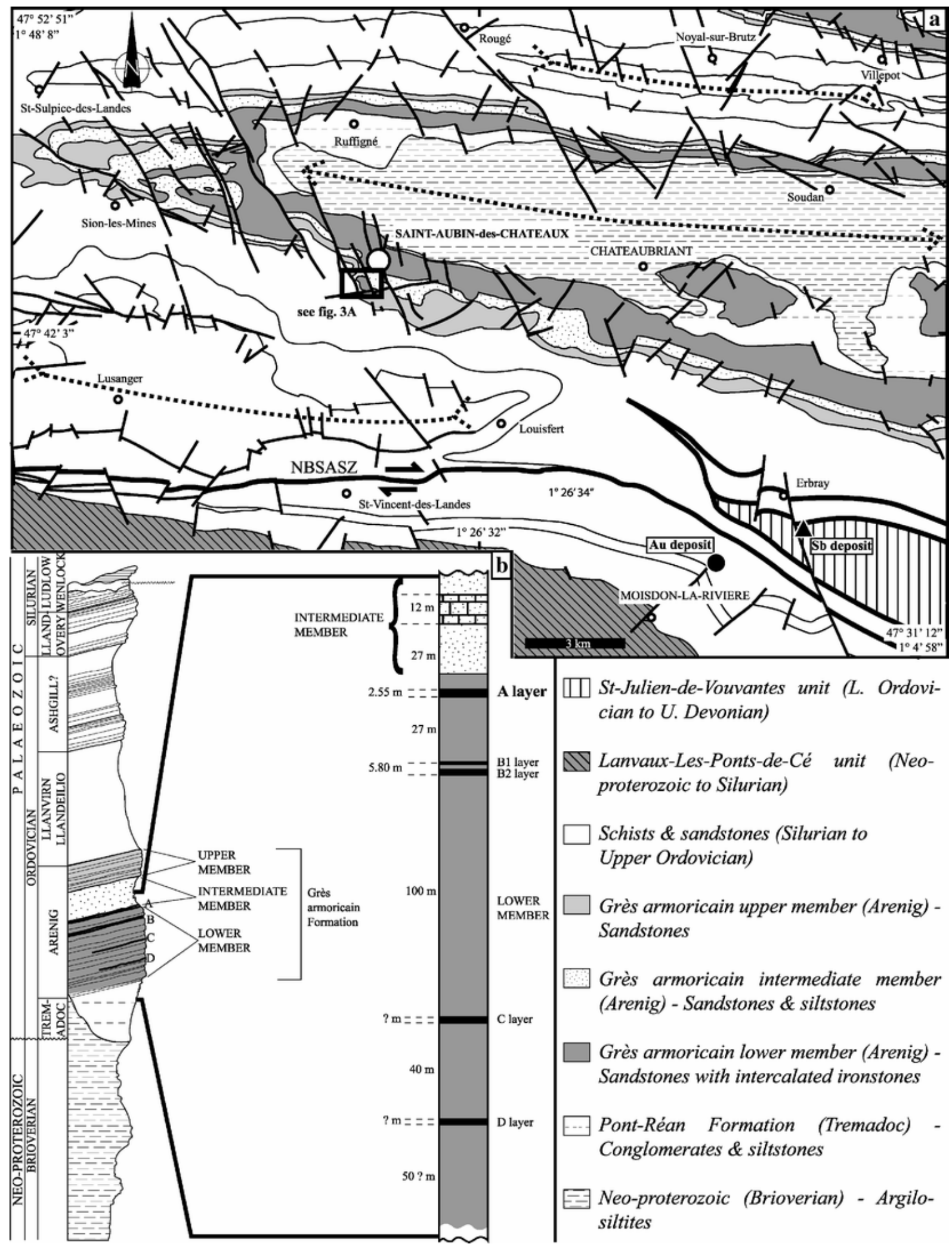

Fig. 2 a Geological map of Châteaubriant area synthesised and simplified from Dadet et al. (1987), Dubreuil et al. (1988), Herrouin et al. (1988) and Trautmann et al. (1987). b Stratigraphic log of the Palaeozoic sequence of the Central Armorican Domain, modified from Dadet et al. (1987). The detailed sequence of ironstones layers $(A$ to $D)$ is modified from Chauvel $(1971,1974)$ 


\section{Structures and deformation}

Palaeozoic sedimentary rocks are well preserved and exposed within $\mathrm{N} 110^{\circ} \mathrm{E}$-trending upright folds, south of Rennes (Fig. 1b). The large buckling wavelength is controlled by the thick and competent Grès armoricain Formation (up to $600 \mathrm{~m}$, Noblet 1983). These folds and the associated $\mathrm{N} 110^{\circ} \mathrm{E}$-trending regional cleavage, which bears a sub-horizontal stretching lineation, are linked to ductile shearing along the NBSASZ. This deformation corresponds to regional-scale dextral simple shear that affected the whole CAD during the Carboniferous (Le Corre 1978; Gapais and Le Corre 1980; Choukroune et al. 1983; Gumiaux 2003). In the CAD, strain intensity increases from north to south and reaches a maximum near the NBSASZ (Gapais and Le Corre 1980, Fig. 1b). From macro- to microscopic scale, the CAD is affected by important vertical fracturing (strike-slip faults and extensional fractures, see Figs. $1 \mathrm{~b}$ and 2a). The major regional fractures have a dominant $\mathrm{N} 160^{\circ} \mathrm{E}$ orientation and are oblique to fold axes. Choukroune et al. (1983) demonstrated that this fracturing was compatible and coeval with the CAD-scale Carboniferous dextral simple shear that occurred via successive incremental deformation during clockwise rotation of principal strain axes. Synkinematic granite intrusions (about 340-330 Ma, Carron et al. 1994) were emplaced along the NBSASZ during Carboniferous dextral wrenching (e.g. Lizio granite, Fig. 1b). These supracrustal intrusions are of laccolith shape and are partially coeval with regional cleavage development within the CAD (Le Corre 1978; Berthé et al. 1979; Vigneresse and Brun 1983; RomanBerdiel et al. 1997).

\section{Ore deposits of the area}

Four types of metallic mineralisation, mostly small scale, have been recognised along the NBSASZ (Chauris and Marcoux 1994, Fig. 1b): (1) Ordovician sedimentary deposits (Zr- and Ti-rich sandstones and oolitic ironstones); (2) Lower Silurian volcanosedimentary $\mathrm{Zn}-\mathrm{Pb}-$ $\mathrm{Cu}-(\mathrm{Ag}-\mathrm{Au})$ deposits, localised within the Saint-Georges-sur-Loire unit; (3) Quartzcassiterite veins associated with leucogranites (e.g. La Villeder, $200 \mathrm{t}$ Sn produced during the nineteenth century) and (4) Late Hercynian polymetallic ( $\mathrm{Pb}, \mathrm{Sb}, \mathrm{Cu}, \mathrm{Zn}, \mathrm{Au})$ veins and stockworks (e.g. La Lucette, Pontpéan, Fig. 1b) linked to regional or local shear zones and/or emplacement of the late Hercynian granites.

\section{Local setting of the oolitic ironstone}

The quarry, locally named the "Bois-de-la-Roche" quarry, is located in the southern limb of the Châteaubriant anticline (Fig. 2a). Iron ore mining occurred within the Lower Member of the Grès armoricain Formation in two main pits split by the La Chère river (Figs. 2b and 3a). The intermediate member lies conformably on the lower member. 


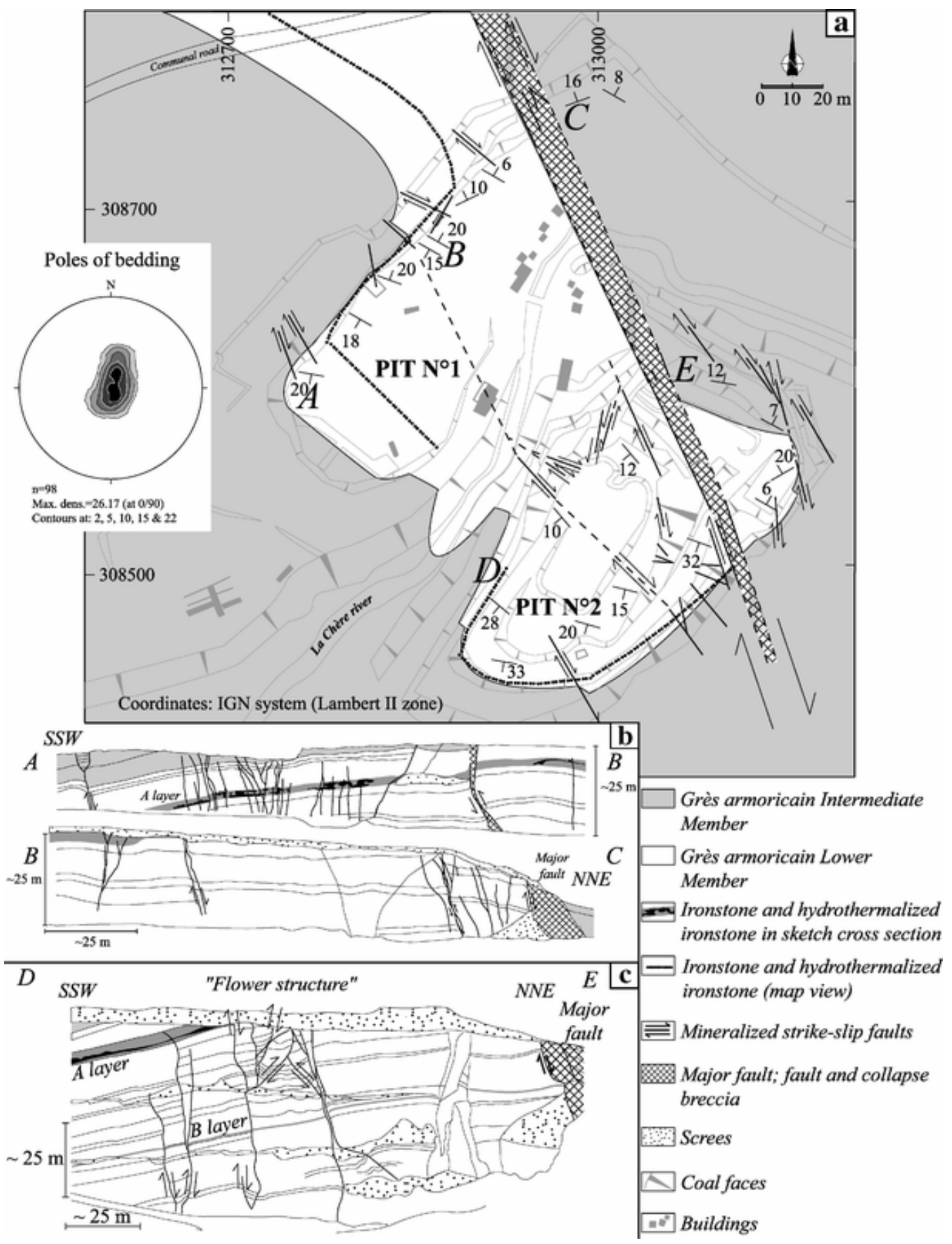

Fig. 3 a Geological map of the Saint-Aubin-des-Châteaux quarry modified from Gloaguen (2002). The quarry is hosted within the Lower and Intermediate Members of the Grès armoricain Formation. Oolitic ironstone A-layer is symbolised by a black dashed line. Note the important density of conjugate dextral and sinistral strike-slip faults. Bedding of sandstones from both members is plotted in stereogram projection (equal area, lower hemisphere). b Cross-section of the north-western part of pit 1 (location on Fig. 3a), showing oolitic ironstone A-layer near the top of the Lower Member (thick grey line). Massive sulphide lenses within ironstone A-layer are in black. Note the strong spatial relationship between massive sulphide lenses and strike-slip faults. c Crosssection of the western part of the pit 2 showing "flower structure" related to strike-slip faults. A- and B-layer represented by thick grey lines 
Bedding is generally WNW trending with a broad low SSW dip, from horizontal to $30^{\circ}$ (Fig. 3a). Locally, the dip direction is disturbed by tilting along a $\mathrm{N} 155^{\circ} \mathrm{E}$-trending major vertical fault (Fig. 4a) and collapse and folding induced by secondary faults (Figs. 3 and 4b). Most faults are dextral strike-slip faults with a small normal component that produced negative flower structures (Fig. 3c). These faults belong to the regional fracture system previously discussed. Extensional fracture orientation and fault-slip data analysis are presented below.
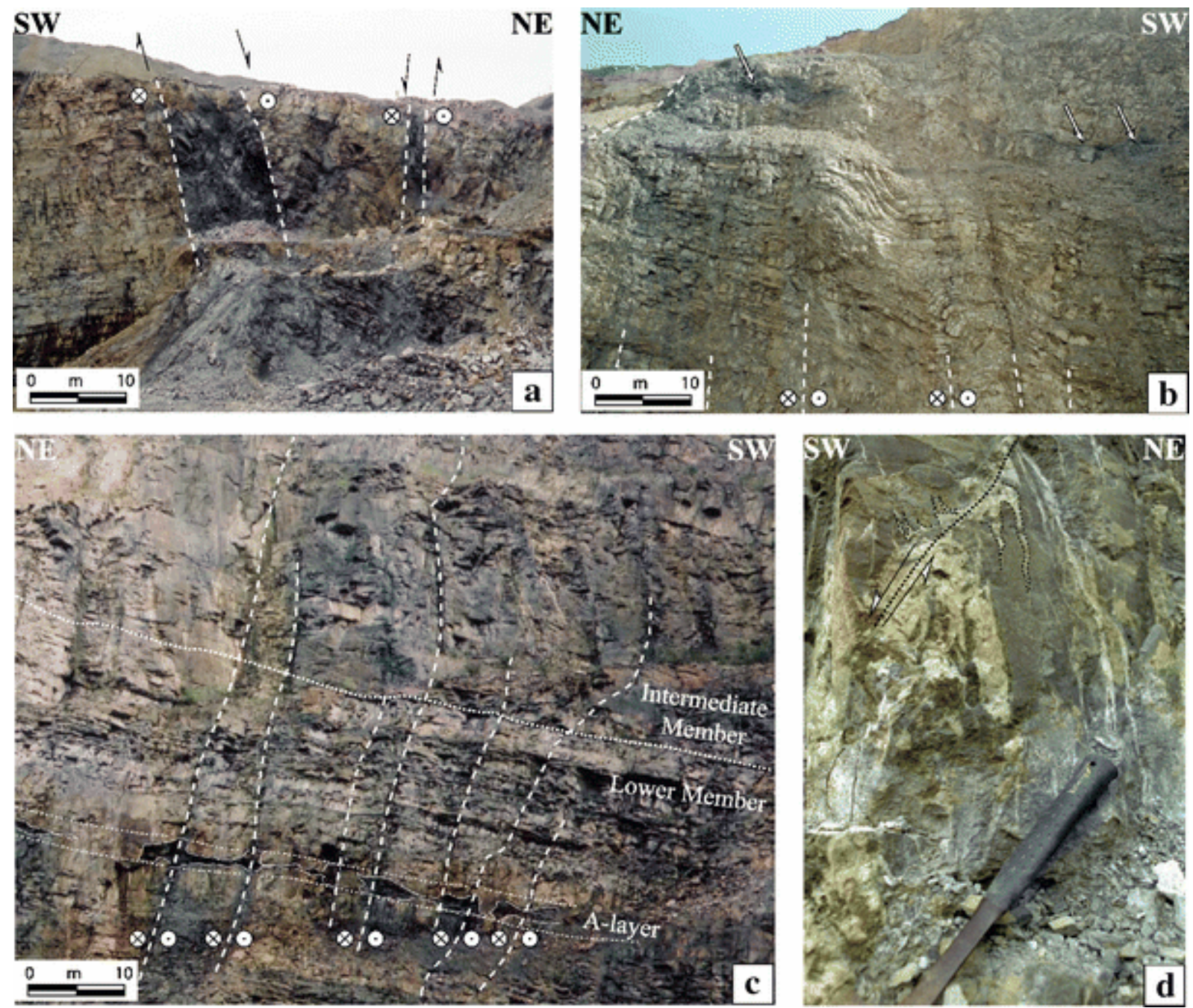

Fig. 4 a Major fault of the quarry (dextral strike-slip fault with a low normal component). The large amount of sulphides (mainly pyrite) within the fault zone is responsible for its dark colour. b View of the northern front of the pit 2, showing folds induced by strike-slip faults. Ironstone A-layer is present on the upper part of the photograph, arrows indicate main massive sulphide lenses. c View of the southern front of the quarry showing the spatial relation between massive sulphide lenses (contours underlined in white) and the sulphide-bearing strike-slip faults crosscutting the ironstone A-layer. d En echelon quartz-chlorite tension gashes crosscut and deformed by a sinistral quartz shear vein (dotted line) containing traces of pyrite and galena (stage 2) 
Four main horizons of oolitic ironstones, hereafter named A to D from top to bottom (Fig. 2b), have been recognised and mined within the Lower Member (Davy 1880; Bellanger 1911; Kerforne 1914; Puzenat 1939; Chauvel 1971, 1974). Only the A and B horizons are exposed at the Saint-Aubin-des-Châteaux quarry (A in pit no. 1, A and B in pit no. 2, Fig. 3b and c). Because of the low quality of B-horizon exposures, we have focused on the A-oolitic ironstone horizon $(\mathrm{OIH})$. OIH varies from dark to black colour and is around $2 \mathrm{~m}$ thick with a maximum of $2.55 \mathrm{~m}$ (Chauvel 1971, 1974). At outcrop scale, OIH is heterogeneous because of the occurrence of lenticular stratoid massive sulphide bodies, mainly composed of pyrite (Figs. 3b,c and 4c). These sulphide lenses within the $\mathrm{OIH}$ have been formerly interpreted as syngenetic massive sulphide deposits (Herrouin et al. 1989). However, Moëlo et al. (2000) and Gloaguen (2002) argued that hydrothermal alteration produced epigenetic sulphidation of the OIH. Consistently, a strong spatial correlation is observed between the development of the sulphide lenticular bodies within OIH and vertical fault traces across OIH (Figs. $3 b$ and 4c). In both pits, the whole sedimentary sequence, including $\mathrm{OIH}$, is affected by important quartz veining expressed by numerous extensional veins and shear veins. As faults, these veins are filled with hydrothermal parageneses including base-metal sulphides (Fig. 4d). In the quarry, sandstones and $\mathrm{OIH}$ underwent diagenesis and very low-grade metamorphism (Le Corre 1978) with no cleavage development.

\section{The oolitic ironstone}

\section{Petrography}

In the quarry, the lower member of the Grès armoricain Formation is homogeneous and composed of dark grey massive sandstone beds (maximum $1.5 \mathrm{~m}$ thick) intercalated with thin dark pelite beds. The sandstone beds are mainly composed of weakly recrystallised quartz grains $(100-150 \mu \mathrm{m})$, the remaining $(10 \%)$ corresponding to chlorite, detrital muscovite, tourmaline, zircon, rutile and organic matter responsible for the dark colour of the unit. Sedimentary structures like ripple marks, mud cracks and load casts are common on bedding surfaces.

Where not affected by hydrothermal alteration, the primary texture of OIH corresponds to oolites with a nucleus of variable nature (detrital quartz, zircon, monazite and diagenetic apatite, siderite or chamosite) and a poorly laminated chamosite cortex (Fig. 5a). The matrix is made of siderite cement in which organic matter particles are widespread. Oolitic texture distribution is not homogeneous, the matrix may largely dominate locally with few sparse oolites only. 


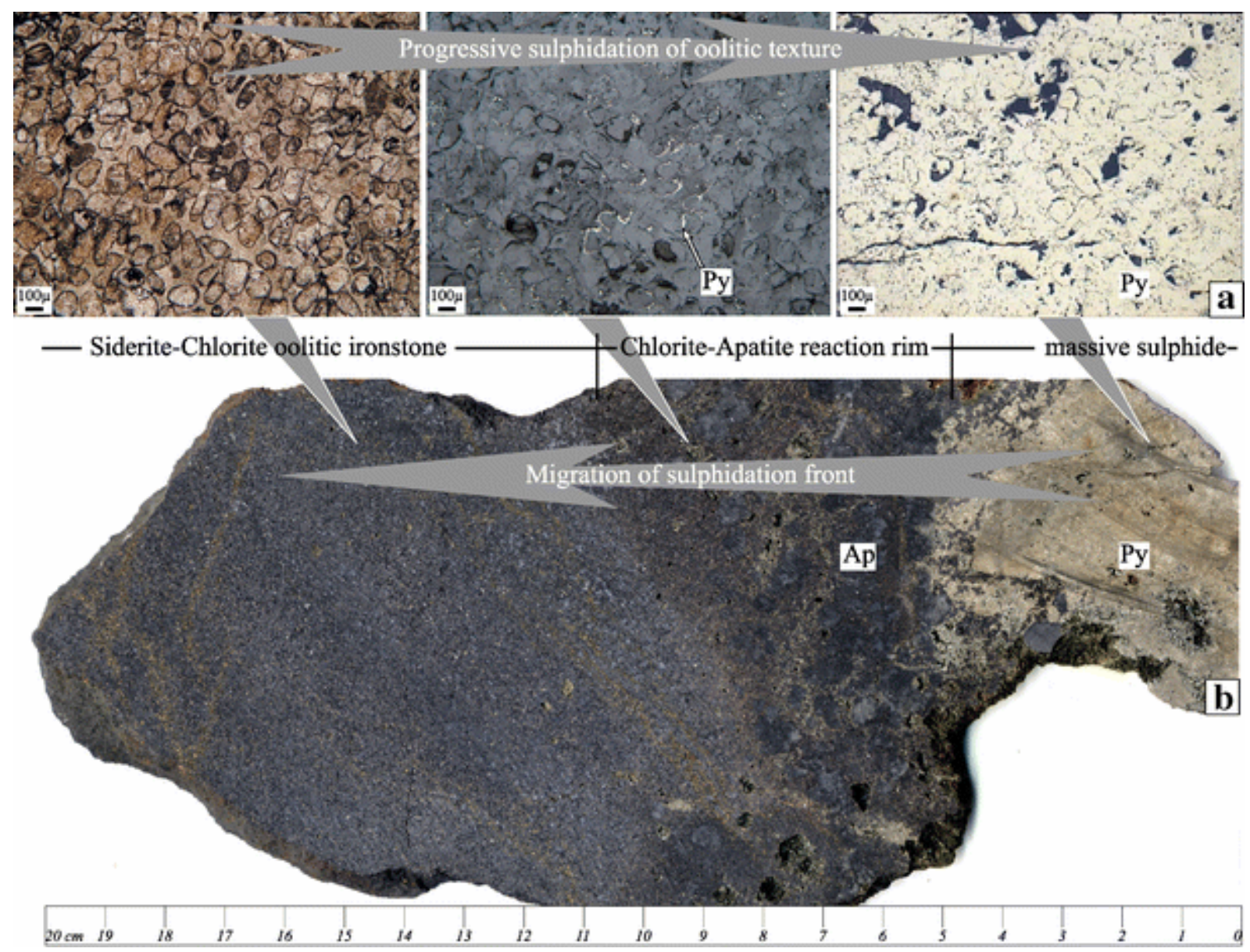

Fig. 5 a Photographs showing the progressive sulphidation of the oolitic ironstone, with, from left to right, (1) non-altered chlorite-siderite oolitic facies (plane polarised transmitted light [PPTL]); (2) oolitic facies with pyrite (Py) surrounding oolites (plane polarised reflected light [PPRL]) and (3) massive sulphide (mainly pyrite) with oolite ghosts underlined by graphite, graphitoids and residual chlorite [PPRL]. b Handle sample showing both oolitic ironstone (left), massive sulphide (right) and the sulphidation reaction rim. This reaction rim contains macroscopic apatite (Ap), red chlorite (Chl) and disseminated arsenopyrite (Apy) and pyrite. Dissolution cavities correspond to siderite (ironstone matrix) dissolved by hydrothermal fluids

Diagenesis is responsible for the growth of Sr-bearing fluorapatite (Chauvel and Phan 1965). This is consistent with geochemical anomalies observed in bulk-rock analyses (see below).

\section{Geochemistry of OIH}

Analyses of major, trace and rare earth elements of nine samples from the oolitic ironstone Alayer from the CAD are reported in Table 1. Seven of them have been taken outside of SaintAubin-des-Châteaux to obtain a regional geochemical average. 
Table 1 Major, minor and trace elements of the Ordovician A-layer oolitic ironstone of the Central Armorican Domain

\begin{tabular}{|c|c|c|c|c|c|c|c|c|c|c|c|}
\hline Sample & Pfe 01 & Pfe 02 & Pfe 03 & Pfe 04 & Pfe 07 & Pfe 09 & Pfe 11 & Pfe 22 & Pfe 24 & $\begin{array}{l}\text { Av. } n=7 \\
\text { localities }\end{array}$ & SE \\
\hline Location & $\begin{array}{l}\text { St-Aubin- } \\
\text { des- } \\
\text { Châteaux- } \\
\text { pit 1 }\end{array}$ & $\begin{array}{l}\text { St-Aubin- } \\
\text { des- } \\
\text { Châteaux- } \\
\text { pit } 2\end{array}$ & $\begin{array}{l}\text { Angrie- } \\
\text { La } \\
\text { Boserie }\end{array}$ & $\begin{array}{l}\text { Angrie- } \\
\text { La } \\
\text { Boserie }\end{array}$ & $\begin{array}{l}\text { Chazé- } \\
\text { Henry- } \\
\text { Chazé }\end{array}$ & $\begin{array}{l}\text { Sion-les- } \\
\text { Mines- } \\
\text { Claray }\end{array}$ & $\begin{array}{l}\text { Teillay- } \\
\text { La Brutz }\end{array}$ & $\begin{array}{l}\text { Saint-Malo- } \\
\text { de-Phily- } \\
\text { Montserrat }\end{array}$ & $\begin{array}{l}\text { Angrie- } \\
\text { La Gare } \\
\text { d'Angrie }\end{array}$ & & \\
\hline $\begin{array}{l}\mathrm{SiO}_{2} \\
(\mathrm{wt} \%)\end{array}$ & 31.94 & 14.65 & 22.50 & 15.84 & 38.94 & 33.81 & 14.38 & 53.14 & 8.68 & 26.76 & 6.00 \\
\hline $\mathrm{Al}_{2} \mathrm{O}_{3}$ & 7.21 & 16.22 & 6.38 & 4.93 & 5.22 & 5.64 & 4.65 & 2.23 & 7.22 & 5.18 & 0.59 \\
\hline $\mathrm{Fe}_{2} \mathrm{O}_{3}{ }^{\mathrm{a}}$ & 41.58 & 45.00 & 60.82 & 64.19 & 37.44 & 52.20 & 64.61 & 34.37 & 50.84 & 52.07 & 4.65 \\
\hline $\mathrm{MnO}$ & 0.26 & 0.16 & 0.06 & 0.30 & 0.16 & 0.20 & 0.10 & 0.90 & 0.20 & 0.27 & 0.11 \\
\hline $\mathrm{MgO}$ & 1.10 & 1.24 & 0.72 & 0.65 & 0.93 & 1.68 & 0.46 & 1.01 & 3.30 & 1.25 & 0.37 \\
\hline $\mathrm{CaO}$ & 0.49 & 4.31 & 1.35 & 5.89 & 8.63 & 2.21 & 1.37 & 1.78 & 2.93 & 3.45 & 1.05 \\
\hline $\mathrm{Na}_{2} \mathrm{O}$ & nd & nd & nd & nd & 0.05 & nd & nd & nd & nd & 0.01 & 0.01 \\
\hline $\mathrm{K}_{2} \mathrm{O}$ & nd & nd & nd & nd & 0.70 & 0.27 & 0.16 & nd & nd & 0.16 & 0.10 \\
\hline $\mathrm{TiO}_{2}$ & 0.37 & 0.57 & 0.27 & 0.25 & 0.49 & 0.51 & 0.57 & 0.17 & 0.35 & 0.37 & 0.06 \\
\hline $\mathrm{P}_{2} \mathrm{O}_{5}$ & 0.83 & 2.62 & 0.70 & 3.27 & 4.78 & 1.43 & 0.64 & 0.82 & 0.85 & 1.78 & 0.61 \\
\hline LOI & 16.46 & 14.87 & 7.05 & 4.54 & 2.72 & 2.32 & 13.52 & 5.38 & 25.48 & 8.72 & 3.13 \\
\hline Total & 100.24 & 99.64 & 99.85 & 99.86 & 100.06 & 100.27 & 100.46 & 99.80 & 99.85 & 100.02 & 0.10 \\
\hline As (ppm) & 18.70 & 13.30 & 12.30 & 18.20 & 27.50 & 2.61 & 5.31 & 4.95 & 37.70 & 15.51 & 4.97 \\
\hline $\mathrm{Ba}$ & 369.0 & 32.2 & 14.1 & 13.5 & 493.0 & 340.0 & 226.0 & 43.4 & 55.2 & 169.3 & 71.4 \\
\hline $\mathrm{Be}$ & 3.35 & nd & 5.01 & 4.38 & 13.10 & 6.59 & 7.67 & 3.97 & 3.21 & 6.28 & 1.28 \\
\hline $\mathrm{Bi}$ & nd & 0.64 & 1.49 & 2.07 & 0.60 & 0.50 & 0.91 & 0.14 & 1.71 & 1.06 & 0.27 \\
\hline Co & 40.2 & 12.8 & 109.0 & 110.0 & 69.7 & 30.5 & 24.6 & 19.2 & 42.9 & 58.0 & 14.7 \\
\hline $\mathrm{Cr}$ & 32.8 & 109.0 & 71.9 & 67.0 & 33.1 & 49.9 & 72.1 & 50.1 & 110.0 & 64.9 & 9.3 \\
\hline Cs & nd & nd & 0.65 & 0.51 & 12.00 & 3.66 & 0.81 & 1.64 & 0.69 & 2.85 & 1.58 \\
\hline $\mathrm{Cu}$ & 5.2 & 63.3 & 10.7 & 8.0 & 5.7 & 13.6 & 0.0 & 0.0 & 11.1 & 7.0 & 2.0 \\
\hline $\mathrm{Ga}$ & 14.40 & 36.80 & 14.00 & 12.50 & 9.41 & 13.90 & 15.50 & 7.04 & 11.90 & 12.04 & 1.11 \\
\hline $\mathrm{Ge}$ & 6.24 & 5.43 & 4.17 & 3.84 & 1.50 & 3.08 & 2.59 & 0.97 & 2.15 & 2.61 & 0.44 \\
\hline Hf & 3.34 & 8.60 & 2.16 & 2.15 & 12.70 & 10.80 & 8.48 & 4.52 & 1.72 & 6.08 & 1.72 \\
\hline Mo & 0.43 & 3.58 & 2.73 & 3.55 & 0.62 & 7.13 & 4.76 & 1.02 & 3.05 & 3.27 & 0.84 \\
\hline $\mathrm{Nb}$ & 7.25 & 11.60 & 11.40 & 10.50 & 7.48 & 8.62 & 9.88 & 2.93 & 14.60 & 9.34 & 1.37 \\
\hline $\mathrm{Ni}$ & 28.7 & 27.6 & 162.0 & 135.0 & 27.7 & 19.1 & 23.5 & 16.0 & 84.4 & 66.8 & 23.0 \\
\hline $\mathrm{Pb}$ & nd & nd & nd & nd & 17.50 & 6.91 & 7.22 & 2.20 & 0.68 & 4.93 & 2.40 \\
\hline $\mathrm{Sb}$ & 2.84 & 35.30 & 5.65 & 7.97 & 4.39 & 5.38 & 0.33 & 1.97 & 0.34 & 3.72 & 1.10 \\
\hline $\mathrm{Sn}$ & 1.24 & 0.86 & 1.02 & 1.31 & 1.12 & 1.07 & 1.85 & 1.19 & 2.89 & 1.49 & 0.26 \\
\hline $\mathrm{Sr}$ & 3959.0 & 3063.0 & 62.4 & 213.0 & 1384.0 & 2698.0 & 318.0 & 185.0 & 103.0 & 709.1 & 373.9 \\
\hline $\mathrm{Ta}$ & 0.60 & 0.93 & 0.64 & 0.59 & 0.76 & 0.79 & 0.90 & 0.32 & 0.68 & 0.67 & 0.07 \\
\hline Th & 6.25 & 23.70 & 15.40 & 16.40 & 17.30 & 18.40 & 11.80 & 5.03 & 24.70 & 15.58 & 2.29 \\
\hline $\mathrm{U}$ & 15.50 & 6.90 & 4.06 & 5.31 & 11.00 & 4.81 & 12.30 & 9.97 & 1.85 & 7.04 & 1.51 \\
\hline $\mathrm{V}$ & 152 & 1230 & 267 & 278 & 203 & 504 & 709 & 252 & 212 & 346 & 72 \\
\hline W & 1.65 & 3.44 & 24.20 & 43.30 & 1.78 & 3.15 & 4.67 & 2.01 & 9.01 & 12.59 & 5.92 \\
\hline $\mathrm{Y}$ & 34.6 & 217.0 & 88.7 & 183.0 & 69.5 & 113.0 & 163.0 & 42.2 & 40.1 & 99.9 & 21.3 \\
\hline $\mathrm{Zn}$ & 183.0 & 543.0 & 149.0 & 160.0 & 137.0 & 146.0 & 75.2 & 47.0 & 132.0 & 120.9 & 16.1 \\
\hline $\mathrm{Zr}$ & 151 & 350 & 102 & 107 & 533 & 471 & 401 & 198 & 76 & 270 & 73 \\
\hline $\mathrm{La}$ & 18.6 & 78.3 & 68.4 & 85.5 & 38.9 & 42.3 & 33.5 & 14.4 & 25.9 & 44.1 & 9.3 \\
\hline $\mathrm{Ce}$ & 38.9 & 241.0 & 230.0 & 289.0 & 92.2 & 117.0 & 108.0 & 44.3 & 74.5 & 136.4 & 33.6 \\
\hline $\mathrm{Pr}$ & 4.35 & 27.70 & 18.30 & 24.20 & 10.50 & 12.90 & 12.80 & 4.51 & 7.95 & 13.02 & 2.48 \\
\hline $\mathrm{Nd}$ & 16.7 & 129.0 & 85.9 & 115.0 & 41.2 & 55.2 & 57.2 & 19.5 & 34.0 & 58.3 & 12.3 \\
\hline
\end{tabular}




\begin{tabular}{|c|c|c|c|c|c|c|c|c|c|c|c|}
\hline Sample & Pfe 01 & Pfe 02 & Pfe 03 & Pfe 04 & Pfe 07 & Pfe 09 & Pfe 11 & Pfe 22 & Pfe 24 & $\begin{array}{l}\text { Av. } n=7 \\
\text { localities }\end{array}$ & SE \\
\hline Location & $\begin{array}{l}\text { St-Aubin- } \\
\text { des- } \\
\text { Châteaux- } \\
\text { pit 1 }\end{array}$ & $\begin{array}{l}\text { St-Aubin- } \\
\text { des- } \\
\text { Châteaux- } \\
\text { pit } 2\end{array}$ & $\begin{array}{l}\text { Angrie- } \\
\text { La } \\
\text { Boserie }\end{array}$ & $\begin{array}{l}\text { Angrie- } \\
\text { La } \\
\text { Boserie }\end{array}$ & $\begin{array}{l}\text { Chazé- } \\
\text { Henry- } \\
\text { Chazé }\end{array}$ & $\begin{array}{l}\text { Sion-les- } \\
\text { Mines- } \\
\text { Claray }\end{array}$ & $\begin{array}{l}\text { Teillay- } \\
\text { La Brutz }\end{array}$ & $\begin{array}{l}\text { Saint-Malo- } \\
\text { de-Phily- } \\
\text { Montserrat }\end{array}$ & $\begin{array}{l}\text { Angrie- } \\
\text { La Gare } \\
\text { d'Angrie }\end{array}$ & & \\
\hline $\mathrm{Sm}$ & 3.88 & 34.90 & 22.10 & 32.30 & 9.14 & 13.90 & 17.20 & 5.37 & 8.70 & 15.53 & 3.52 \\
\hline $\mathrm{Eu}$ & 0.863 & 6.480 & 5.680 & 8.690 & 2.510 & 3.270 & 4.410 & 1.540 & 2.030 & 4.019 & 0.947 \\
\hline $\mathrm{Gd}$ & 4.55 & 34.00 & 23.30 & 38.70 & 9.66 & 16.40 & 19.70 & 5.97 & 8.72 & 17.49 & 4.26 \\
\hline $\mathrm{Tb}$ & 0.834 & 6.810 & 3.400 & 6.280 & 1.650 & 2.780 & 3.530 & 1.050 & 1.440 & 2.876 & 0.676 \\
\hline Dy & 5.11 & 45.10 & 19.50 & 35.00 & 10.60 & 18.00 & 22.80 & 6.91 & 8.71 & 17.36 & 3.70 \\
\hline Ho & 1.20 & 8.78 & 3.52 & 6.75 & 2.19 & 4.00 & 5.81 & 1.56 & 1.74 & 3.65 & 0.77 \\
\hline $\mathrm{Er}$ & 2.92 & 24.30 & 9.05 & 17.30 & 6.56 & 12.20 & 17.70 & 4.57 & 4.66 & 10.29 & 2.11 \\
\hline $\mathrm{Tm}$ & 0.455 & 4.390 & 1.520 & 2.940 & 1.200 & 2.190 & 2.910 & 0.810 & 0.767 & 1.762 & 0.350 \\
\hline $\mathrm{Yb}$ & 2.83 & 28.30 & 8.67 & 15.90 & 7.60 & 13.10 & 20.70 & 5.98 & 5.24 & 11.03 & 2.17 \\
\hline $\mathrm{Lu}$ & 0.397 & 4.040 & 1.310 & 2.360 & 1.070 & 2.000 & 3.100 & 0.827 & 0.741 & 1.630 & 0.334 \\
\hline
\end{tabular}

Samples Pfe 01 and Pfe 02 are non-altered and hydrothermally altered ironstone, respectively, from the SaintAubin-des-Châteaux quarry. The regional average composition and standard error of the A-Layer ironstone are calculated on seven samples (Pfe 03 to Pfe 24). Whole-rock compositions were determined by ICP-AES for major elements and by ICP-MS for trace and rare elements at CRPG Nancy (France).

$n d$ Below detection limit; $A v$. average; $S E$ standard error

${ }^{\mathrm{a}} \mathrm{Fe}_{2} \mathrm{O}_{3}=$ total $\mathrm{Fe}$ expressed as $\mathrm{Fe}_{2} \mathrm{O}_{3}$

Two samples are from the Saint-Aubin-des-Châteaux quarry. The first one, Pfe 01, comes from the upper part of the Pit no. 1 (Fig. 3). This sample is a fine-grained oolitic chamositesiderite ironstone, without hydrothermal alteration.

The second sample, Pfe 02, comes from a strongly hydrothermally overprinted area in the lowest part of Pit 2 (Fig. 3). This sample is a recrystallised fine-grained chloritic sample with disseminated apatite and rare sulphides. Some veinlets of quartz, apatite and minor sulphides crosscut the sample.

At a regional scale, the chemical variations in major elements of the ironstone reflect mainly the changes in mineralogy (Chauvel 1971). Indeed, in the eastern part of the CAD, ironstones are composed of oxides (magnetite and/or hematite) and silicates (chamosite, stilpnomelane), whereas in the western part, the ironstones are mainly composed of Fe-carbonates (siderite) and silicates (chamosite). Thus, major element composition reflects mainly sedimentary conditions, which are out of the scope of this study, and only trace elements are discussed here. For trace elements, samples have been normalised to the regional geochemical average (Fig. 7).

With the exception of sample Pfe 02 (hydrothermally overprinted), all samples have a homogenous composition for most trace elements (samples/average ratios between 0 and 3 ). The OIH at Saint-Aubin-des-Châteaux is abnormally rich in $\mathrm{Sr}, \mathrm{Ge}, \mathrm{Ba}$ and $\mathrm{U}$ relative to the other samples of A-layer oolitic ironstone. Like the major elements $\mathrm{Fe}, \mathrm{Ca}$ and $\mathrm{P}$, the trace elements $\mathrm{Sr}$ and $\mathrm{Ba}$ have been interpreted as a result of chemical precipitation from weathered continental crust (Franceschelli et al. 2000). The "trapping" role played by organic matter, abundant within sandstones of the quarry, might be responsible for this enrichment too. 


\section{Hydrothermal alteration of $\mathrm{OIH}$}

Two main stages of hydrothermal alteration can be distinguished: a massive sulphidation (stage 1) followed by polymetallic quartz veining (stages 2 and 3). A detailed paragenetic sequence is given in Table 2 .

Table 2 Paragenetic sequence of the Saint-Aubin-des-Châteaux mineralisation

\begin{tabular}{|c|c|c|c|c|c|c|c|}
\hline & & Diagenesis & $\begin{array}{l}\text { Pre-ore stage } \\
\text { metamorphic? }\end{array}$ & $\begin{array}{c}\text { Stage 1 } \\
\text { Massive } \\
\text { sulphidation }\end{array}$ & $\begin{array}{c}\text { Stage } 2 \\
\text { Polymetallic } \\
\text { stage }\end{array}$ & $\begin{array}{c}\text { Stage } 3 \\
\text { Gold-Sulfosalts } \\
\text { stage } \\
\end{array}$ & $\begin{array}{c}\text { Stage } 4 \\
\text { Late carbonate } \\
\text { stage }\end{array}$ \\
\hline & Mineral & & Si-Al-Fe & As & $\mathrm{Cu}-\mathrm{Zn}$ & $\mathrm{Pb}-\mathrm{Sb}-\mathrm{Au}$ & FeS-carbonates \\
\hline & Arsenopyrite & & & E & & & \\
\hline & Pyrite & & & 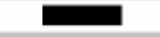 & - & & \\
\hline & Marcasite & & & & & & \\
\hline & Pyrrhotite & & & 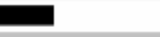 & - & & \\
\hline Sulphides and & Chalcopyrite & & & & & & \\
\hline sulfosalts & Sphalerite & & & & E & - & \\
\hline & Galena & & & & & & \\
\hline & Boulangerite & & & & & & \\
\hline & Bournonite & & & & & & \\
\hline & Tetrahedrite & & & & & & \\
\hline Elements & Electrum & & & & & & \\
\hline & Graphite & & & & & & \\
\hline & Quartz $^{2}$ & & & & & & \\
\hline Oxides & Rutile $^{\mathrm{a}}$ & & & & & & \\
\hline & Ilmenite ${ }^{2}$ & & & & & & \\
\hline & Zircon" & & & & & & \\
\hline & Chamosite & & & & & E & \\
\hline Silicates ${ }^{b}$ & Berthierine & & & & - & & \\
\hline & Tourmaline & & & & & & \\
\hline & White mica & & & & & & \\
\hline & Dickite & & & & & & \\
\hline & Siderite & & & & & & \\
\hline Carbonates & Calcite & & & & & & E \\
\hline & Dolomite & & & & & & - \\
\hline & Fluorapatite & & & & & & \\
\hline & Lulzacite & & & & & & \\
\hline & Goyazite & & & & & & \\
\hline Phosphates & Pretulite & & & & - & & \\
\hline & Xenotime- $(\mathrm{Y})^{\mathrm{d}}$ & & & --- & & & \\
\hline & Monazite- $(\mathrm{Ce})^{\mathrm{d}^{\mathrm{a}}}$ & 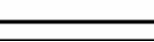 & & --------- & & & \\
\hline
\end{tabular}

${ }^{\mathrm{a}}$ Minerals of detrital origin

${ }^{\mathrm{b}}$ Other silicates, berthierine and stilpnomelane have been described in diagenetic/low metamorphic ironstone facies of Central Armorican Domain (Chauvel 1971) but have not been observed in the quarry.

${ }^{\mathrm{c}}$ Detailed phosphate and zircon mineralogy in Moëlo et al. (2002).

${ }^{\mathrm{d}}$ The exact timing of xenotime and monazite crystallisations remains unclear (metamorphic and/or related to stage 1 hydrothermalism?).

\section{Massive sulphidation of OIH (stage 1)}

The sulphide lenses are mostly composed of abundant pyrite I, forming anhedral aggregates or perfect cubic crystals (up to $10 \mathrm{~cm}$ ) and containing between 0.06 and $0.8 \mathrm{wt} \%$ As (Fig. 5b). Progressive replacement of the oolitic texture by pyrite results in oolite pseudomorphs (i.e. "ghosts") preserved locally within the massive sulphide lenses (Fig. 5a). All degrees of substitution through pyritisation can be observed in OIH with the chlorite-siderite association being successively destabilised and recrystallised near the reaction rim (Fig. 5a,b and c). 


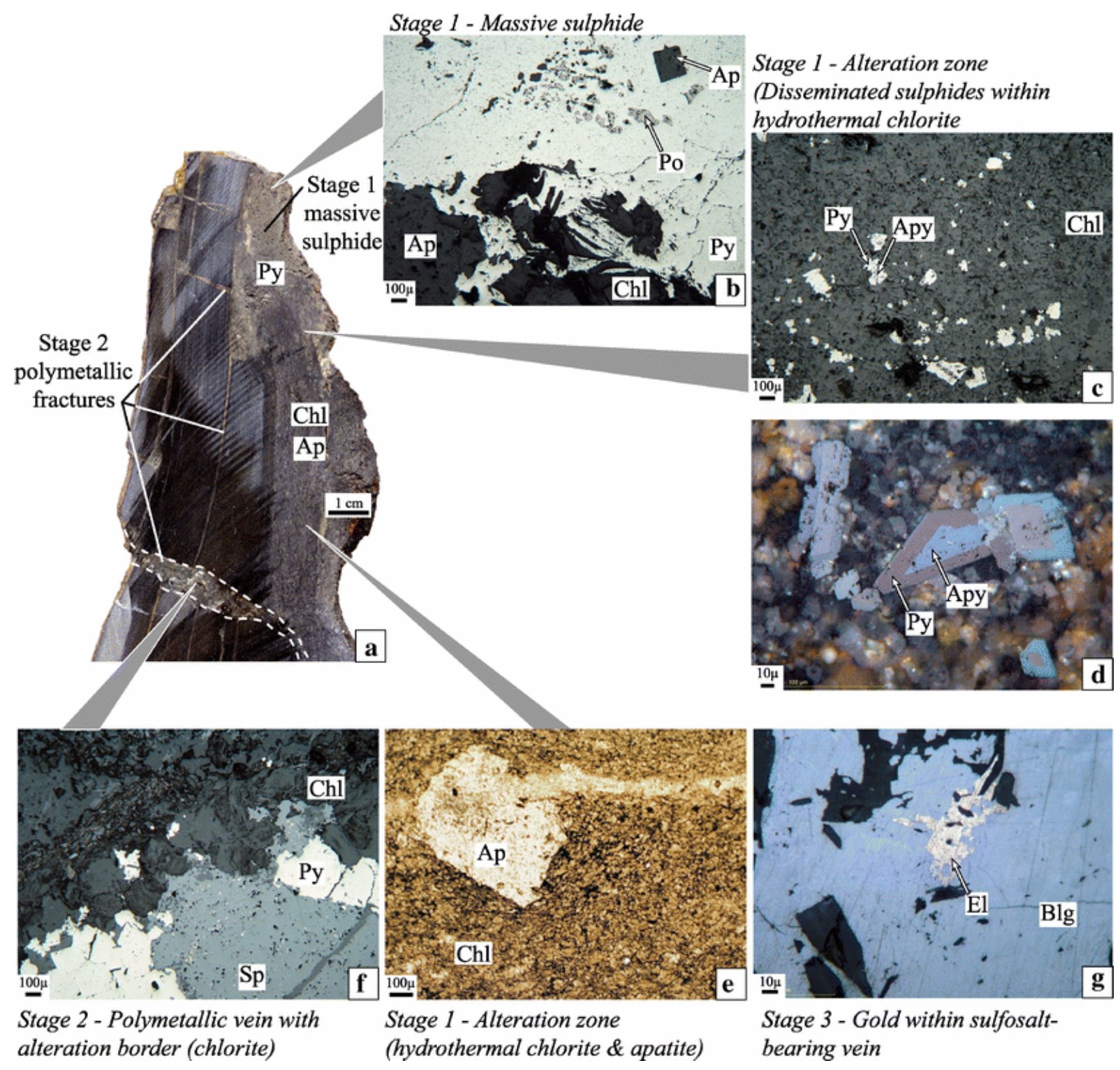

Fig. 6 a Hand sample with massive sulphide (top right) and hydrothermally altered ironstone with apatite and chlorite (right) crosscut by fractures filled with stage 2 paragenesis (white dashed line). b Massive sulphide (pyrite) including euhedral apatite, chlorite lamellae and pyrrhotite (Po) [PPRL]. c Chlorite-dominant ironstone facies with disseminated arsenopyrite and pyrite [PPRL]. d Detailed view of disseminated arsenopyrite crystals with surrounding pyrite [cross plane reflected light]. e Macroscopic apatite-bearing chloritic ironstone facies from the reaction rim. Black areas between chlorite grains are a mixture of graphite and graphitoids. Detrital zircons with epitactic xenotime-(Y) and pretulite (Moëlo et al. 2002) are frequently observed in this facies [PPTL]. f Stage 2 polymetallic paragenesis in a fracture within ironstone. This paragenesis is marked by euhedral pyrite crystals (white) and anhedral sphalerite ( $\mathrm{Sp}$, light grey, right bottom) including pyrrhotite and numerous chalcopyrite spots typical of the "chalcopyrite disease" phenomenon. A fringe of red chlorite (dark grey) separates sulphide infill from ironstone (top, left) [PPRL]. g Stage 3, with gold (electrum, El) included in boulangerite (Blg). Quartz, chlorite and tourmaline are in black [PPRL]

The massive sulphidation of $\mathrm{OIH}$ is also characterised by (1) marcasite (locally up to 50 vol.\%) forming either twin euhedral crystals or replacing former pyrrhotite; (2) disseminated pyrrhotite forming sections up to $1 \mathrm{~mm}$ in length, which appear to be in equilibrium with pyrite I (Fig. 6b); (3) euhedral arsenopyrite $(<5 \mathrm{~mm})$ dispersed in pyrite I or surrounded by pyrite I in partially sulphide facies (Fig. 6c and d); (4) various generations of hydrothermal apatite with variable Sr content (Moëlo et al. 2000, Figs. 5b and 6a,b and e); (5) 
red-brown chamosite (Fig. 6b) and (6) organic matter particles (graphitoids, graphite) in ironstone dissolution cavities, as inclusions within pyrite I (Fig. 5a) or in between chamosite or mixed chamosite-siderite grains (Fig. 6e).

The periphery of the massive sulphide lenses is underlined by a reaction rim, around 10 to $30 \mathrm{~cm}$ thick, which marks the migration of the sulphidation front across the OIH (Figs. 5a,b and 6a). Associated with incipient sulphidation marked by pyrite and arsenopyrite, the reaction rim is characterised by (1) the presence of abundant milky hydrothermal apatite and red-brown chlorite in front of massive sulphide; (2) siderite dissolution cavities within $\mathrm{OIH}$, recrystallised chlorite and graphite lamellae constituting the matrix and (3) development of a rare association of rare earth elements-phosphates (pretulite, xenotime-(Y) and monazite(Ce), see Moëlo et al. 2002 for detailed mineralogy). Migration of the sulphidation front is marked by progressive pyritisation and replacement of oolites as well as by inclusions in massive sulphide lenses of red-brown chamosite and hydrothermal apatite (Fig. 6b).

In front of some lobes, the massive sulphide lenses present parallel bedding veins (Fig. 8) filled with siderite, quartz, pyrite, graphite lamellae and lulzacite, which is an original Srphosphate (type locality, Moëlo et al. 2000). The position at the interbeds, the laminated textures and horizontal slickensides observed along the wallrocks indicate that these parallelbedding veins formed during $\mathrm{OIH}$ interbed slipping. Slipping might be induced by flexural slip folding associated with buckling along wrench faults (Fig. 4b). The formation of these parallel-bedding veins is also related to the dissolution of siderite from the ironstone at the massive sulphide front. Some of these parallel-bedding veins are believed to have formed at the end of the main stage 1 . Veins probably reopened at the beginning of the polymetallic stage 2 , which may explain the scarcity of galena in these lenses.

The massive sulphide lenses within OIH coincide with the strike-slip faults along the quarry fronts (Figs. 4c and 8). The sulphide lenses generally extend symmetrically on each side of the faults. In the surrounding sandstones, major faults are characterised by a $10-\mathrm{m}$ thick crushed dark zone of clay gouge associated with laminated quartz, green chlorite and pyrite shear veins with locally breccia textures (Fig. 4a). Cockade breccias, massive pyritisation of gouge, pyrite clasts and other internal breccia textures provide evidence for cyclic faultinduced fluid flow. However, through the $\mathrm{OIH}$, this complex crushed fault zone dies out and is relayed within $\mathrm{OIH}$ by a regular stockwork formed by thin $(1-5 \mathrm{~mm})$ conjugate quartzsiderite-pyrite vertical shear veinlets (Fig. 8). In association with bedding-parallel shear veins, these conjugate shear veinlets segment the OIH into decimetric "cubes" with pervasive massive sulphidation marked by pyrite and marcasite nodules. Locally, the ironstone cubes are strongly dissolved leading to the development of a spectacular boxwork at the bottom of faults (Fig. 8).

\section{Base metal deposition in veins (stage 2)}

A second hydrothermal paragenesis, the polymetallic $\mathrm{Cu}-\mathrm{Zn}$ stage, is observed in veins or veinlets that are localised in $\mathrm{OIH}$ and surrounding sandstone (Fig. 8, Table 2). Within $\mathrm{OIH}$, these veins crosscut massive sulphide lenses and reaction rims (Fig. 6a and f) and reopened former veins and interbeds. Within sandstone, faults, tension gashes and shear veins present the same polymetallic paragenesis of mainly quartz, pyrite II, sphalerite, chalcopyrite, galena, pyrrhotite and hydrothermal apatite (Fig. 6f). Sphalerite systematically contains numerous inclusions of chalcopyrite droplets (the so-called chalcopyrite disease).

This explains its lowFe content well expressed by the structural formula: (Table 3) 
Table 3 Average electron microprobe analyses (wt\%) and corresponding structural formulae of sulphides from stages 1 to 3

\begin{tabular}{|c|c|c|c|c|c|c|c|}
\hline & $\begin{array}{l}\text { Arsenopyrite } \\
\text { stage 1 }\end{array}$ & $\begin{array}{l}\text { Pyrrhotite } \\
\text { stage 1 }\end{array}$ & \begin{tabular}{|l} 
Pyrrhotite \\
stage 2
\end{tabular} & $\begin{array}{l}\text { Sphalerite } \\
\text { stage 2 }\end{array}$ & \begin{tabular}{|l} 
Boulangerite \\
stage 2
\end{tabular} & $\begin{array}{l}\text { Bournonite } \\
\text { stage } 2\end{array}$ & $\begin{array}{l}\text { Tetrahedrite } \\
\text { stage } 2\end{array}$ \\
\hline & Av. of $n=53$ & Av. of $n=10$ & Av. of $n=10$ & Av. of $n=10$ & Av. of $n=10$ & Av. of $n=16$ & Av. of $n=12$ \\
\hline $\begin{array}{l}\mathrm{Fe} \\
\mathrm{wt} \%\end{array}$ & 32.63 & 61.01 & 59.48 & 7.71 & nd & 0.07 & 3.79 \\
\hline Co & 0.75 & 0.01 & 0.02 & nd & nd & nd & nd \\
\hline $\mathrm{Ni}$ & 0.04 & nd & nd & nd & nd & nd & nd \\
\hline $\mathrm{Cu}$ & - & nd & nd & 0.03 & nd & 13.03 & 37.08 \\
\hline $\mathrm{Au}$ & nd & - & - & - & nd & nd & nd \\
\hline $\mathrm{Ag}$ & - & - & - & - & nd & nd & 1.33 \\
\hline $\mathrm{Zn}$ & - & nd & nd & 57.63 & nd & 0.01 & 4.13 \\
\hline $\mathrm{Pb}$ & - & nd & nd & nd & 55.21 & 42.59 & 0.13 \\
\hline $\mathrm{Cd}$ & - & nd & nd & 0.04 & 0.01 & nd & nd \\
\hline $\mathrm{Hg}$ & - & 0.03 & nd & nd & nd & nd & nd \\
\hline As & 44.15 & nd & 0.02 & nd & 0.45 & 0.5 & 1.13 \\
\hline $\mathrm{Sb}$ & 0.21 & nd & nd & nd & 25.82 & 24.82 & 29.29 \\
\hline S & 20.70 & 39.29 & 39.55 & 33.65 & 18.62 & 19.66 & 25.07 \\
\hline $\mathrm{Se}$ & 0.09 & nd & nd & nd & nd & nd & nd \\
\hline \multirow[t]{2}{*}{ Total } & 98.55 & 100.34 & 99.07 & 99.06 & 100.11 & 100.68 & 101.95 \\
\hline & 3 Atoms & $\Sigma=1$ & $\Sigma=1$ & 2 Atoms & 20 Atoms & 6 Atoms & 29 Atoms \\
\hline $\mathrm{Fe}$ & 0.97 & 0.89 & 0.86 & 0.13 & 0.00 & 0.01 & 1.11 \\
\hline Co & 0.02 & 0.00 & 0.00 & 0.00 & 0.00 & 0.00 & 0.00 \\
\hline $\mathrm{Cu}$ & - & 0.00 & 0.00 & 0.00 & 0.00 & 1.00 & 9.59 \\
\hline $\mathrm{Ag}$ & - & - & - & - & 0.00 & 0.00 & 0.20 \\
\hline $\mathrm{Zn}$ & - & 0.00 & 0.00 & 0.85 & 0.00 & 0.00 & 1.04 \\
\hline $\mathrm{Pb}$ & - & 0.00 & 0.00 & 0.00 & 5.00 & 1.00 & 0.01 \\
\hline As & 0.96 & 0.00 & 0.00 & 0.00 & 0.11 & 0.03 & 0.25 \\
\hline $\mathrm{Sb}$ & 0.00 & 0.00 & 0.00 & 0.00 & 3.98 & 0.99 & 3.95 \\
\hline S & 1.05 & 1.00 & 1.00 & 1.01 & 10.9 & 2.98 & 12.85 \\
\hline \begin{tabular}{|l|} 
As \\
at.\%
\end{tabular} & $31.97 \pm 0.36$ & & & & & & \\
\hline
\end{tabular}

Common analytical laboratory: BRGM-CNRS-Orleans University. Arsenopyrite: CAMECA SX-50 (20 kV, $20 \mathrm{nA})$. Sphalerite and pyrrhotite: CAMECA SX-50 (20 kV, $25 \mathrm{nA})$. Sulphosalts: CAMECA CAMEBAX $(20 \mathrm{kV}, 25 \mathrm{nA})$. Elements and emission lines (standards): Co Ka (cobalt metal), Ni Ka (nickel metal), $\mathrm{Cu} \mathrm{K} \alpha$ (copper metal), $\mathrm{Au} \mathrm{M} \alpha$ (gold metal), $\mathrm{Ag} \mathrm{L} \alpha$ (silver metal), $\mathrm{Zn} \mathrm{K \alpha}$ (sphalerite), $\mathrm{Pb} \mathrm{M} \alpha$ (galena), $\mathrm{Cd} \mathrm{L} \alpha$ (cadmium metal), Hg M $\alpha$ (cinnabar), Sb L $\alpha$ (stibnite), Se L $\alpha$ (selenium metal), Fe K $\alpha$ (pyrite), S Ka (pyrite). Additional standards for arsenopyrite: La Roche-Balue arsenopyrite (Moëlo et al. 1985; Fe Ka, As L $\alpha$ and $\mathrm{S} \mathrm{K} \alpha$ ); for pyrrhotite: troilite $(\mathrm{Fe} \mathrm{K} \alpha$ and $\mathrm{S} \mathrm{K} \alpha)$.

$n d$ Is below detection limit; - is not analysed

\section{Sulphosalt- and gold-bearing quartz veins (stage 3)}

$\mathrm{The} \mathrm{Pb}-\mathrm{Sb}-\mathrm{Au}$ paragenesis is localised within tension gashes and bedding-parallel veins related to the faults that affect $\mathrm{OIH}$ and surrounding sandstone. These veins contain quartz, chamosite, white mica, tourmaline, late galena, chalcopyrite, pyrite III, Sb-sulphosalts (bournonite, boulangerite and tetrahedrite) and electrum (64.3 to $55.5 \mathrm{wt} \% \mathrm{Au}$; Fig. $6 \mathrm{~g}$ ). From 
electron probe microanalyses (EPMA; Table 3), the structural formulae of bournonite, boulangerite and tetrahedrite are $\mathrm{Pb}_{1.00} \mathrm{Cu}_{1.00} \mathrm{Fe}_{0.01} \mathrm{Sb}_{0.99} \mathrm{As}_{0.03} \mathrm{~S}_{2.98}$ (on the basis of a total of 6

atoms), $\mathrm{Pb}_{5.00} \mathrm{Sb}_{3.98} \mathrm{As}_{0.11} \mathrm{~S}_{10.90}$ (total of 20 atoms) and $\quad$ (total of 29 atoms), respectively.

Massive replacement did not occur for the polymetallic stages (2 and 3) within OIH. Finally, late carbonate-pyrite-quartz veins (stage 4) have been observed on isolated blocs, but appear to be scarce in the quarry.

\section{Geochemistry}

The hydrothermally overprinted sample Pfe 02 displays enrichment in $\mathrm{Cu}, \mathrm{Pb}, \mathrm{Sb}$ and $\mathrm{Zn}$. The enrichment factor relative to the protolith of average ironstone A-layer is between 3 and 10 (Fig. 7 and Table 1). The comparison with the non-altered sample Pfe 01 and other regional samples, suggests that the base metal enrichment is not related to the sedimentary conditions; that is, it cannot be ascribed to a syngenetic pre-concentration. Thus, hydrothermal alteration is the likely process responsible for the geochemical signature, through the input of $\mathrm{Cu}, \mathrm{Pb}$, $\mathrm{Sb}$ and $\mathrm{Zn}$ from an external source into $\mathrm{OIH}$.
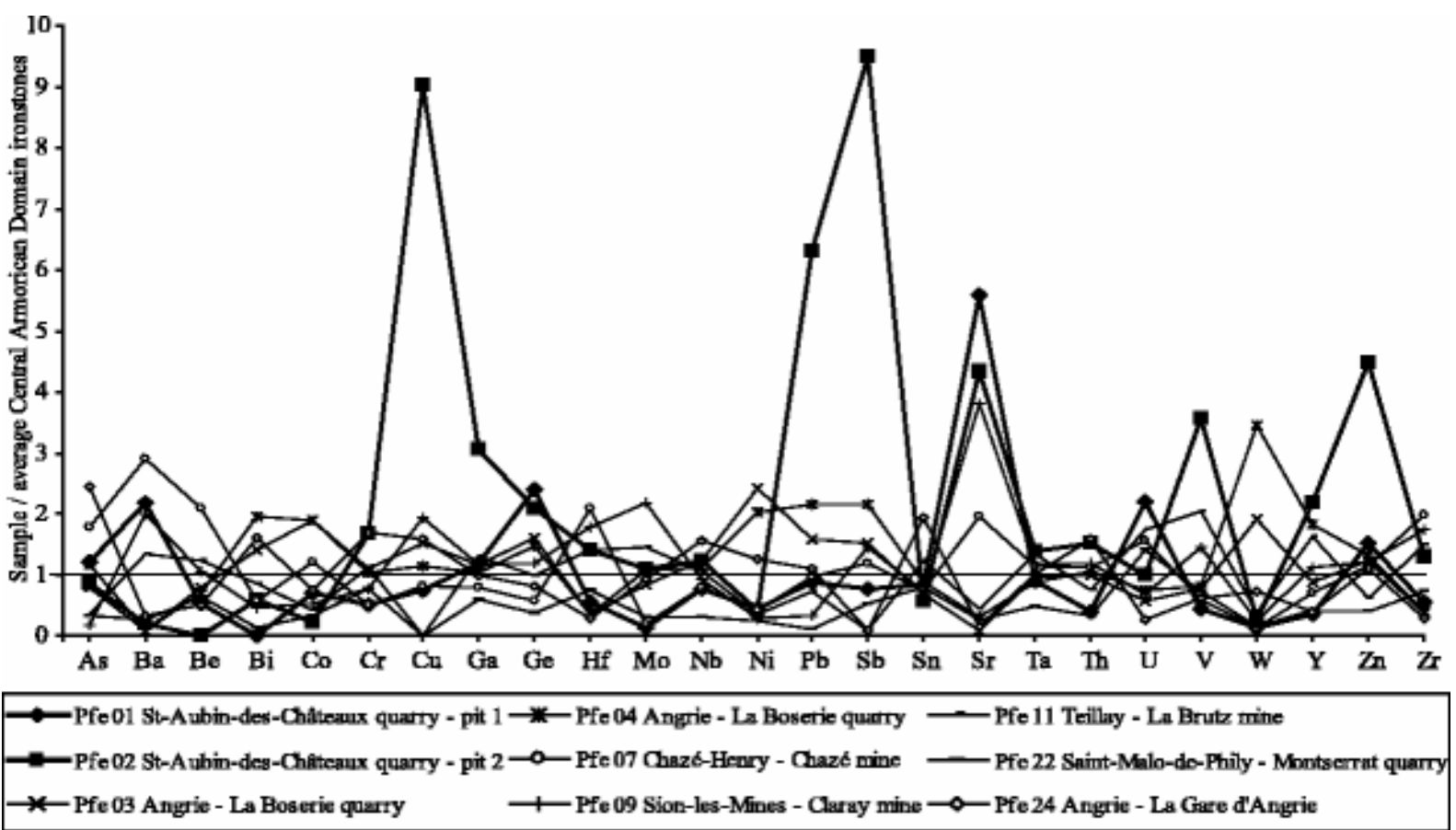

Fig. 7 Comparison of the trace element composition of regional A-layer ironstone with the non-altered (Pfe 01) and hydrothermally altered (Pfe 02) samples from the Saint-Aubin-des-Châteaux quarry. All samples are normalised to the average regional ironstone composition (Table 1)

\section{Deformation analysis}

The fault-slip analysis has been performed using the Right Dihedra method (Angelier and Mechler 1977), and the extensional vein analysis was chronologically constrained by the nature of hydrothermal infill. At the quarry scale, the statistical variations of bedding strike and dip appear to be low enough to interpret the data without untilting them. Bedding-parallel shear veins have not been taken into account. 


\section{Fault-slip analysis}

Structures used for kinematic analysis are shear veins and metric to decametric faults. $\mathrm{N} 150^{\circ}$ E-trending right-lateral major fault zones (Fig. 3a) have been carried out because the strain magnitude is too high along these zones. Shear veins differ from minor faults by the length, which is about 3 and $15 \mathrm{~m}$ maximum, respectively. In the quarry, both shear veins and faults are mainly filled with quartz, green chlorite, siderite and pyrite. Within some faults, gouge has been massively pyritised as massive sulphide lenses in $\mathrm{OIH}$ and is responsible of the dark colour of the damaged zone (Fig. 4a). Slip direction was defined by growth slickensides of quartz and pyrite. Other shear sense criteria are drag folds, classical tectoglyphs, associated Riedel shears and associated en-echelon tension gashes very common in the quarry (Fig. 4d). We have distinguished shear veins in $\mathrm{OIH}$ and surrounding sandstone to assess any potential differences.

The results are presented in Fig. 9. The majority of shear veins and faults are vertical to steady dipping fractures with dominant strike-slip movement. Right Dihedra stereograms clearly show horizontal stretching and shortening axis, which indicate pure wrenching with a mean $\mathrm{N}-\mathrm{S}$ shortening direction. However, even if the number of data is sufficient, a dominant set of conjugate fractures (SE- to SSE-trending for the dominant system) induces large contoured domains (Fig. 9). The orientation of principal stress axis and ellipsoid shape then is subject to some degree of uncertainty. It is noteworthy that within $\mathrm{OIH}$, conjugate shear veins, which form a boxwork at some places (see above), appear to be incompatible with a broad N-S shortening. This point will be discussed below.

\section{Extension veins}

Extension veins do not show slip evidence. In Fig. 8, they appear to be vertical to high-angle dipping, with substantial strike variation. This strike variation can be partly explained by rigid rotation during non-coaxial progressive local deformation (i.e. sigmoidal curved geometry). However, in the quarry, extension veins, arranged in an en-echelon geometry, present generally a low curvature (between 0 and $15^{\circ}$ ), not sufficient to explain the observed variation. The strike separation of tension gash veins has been computed on a rose diagram (Fig. 9). At least three populations can be distinguished with mean strikes of $\mathrm{N} 140^{\circ} \mathrm{E}$ (set 1 ), $\mathrm{N} 160^{\circ} \mathrm{E}$ (set 2), which is the dominant system, and $\mathrm{N} 10^{\circ} \mathrm{E}$ (set 3). Three horizontal shortening directions have been deduced. Sulphides are statistically distributed in tension gashes striking between sets 2 and 3. Quartz is the dominant mineral within veins of set 1. Crosscutting relationships present veins of set 1 cut and offset by en-echelon arrays of sets 2 and 3 (Fig. 8). Between sets 2 and 3, crosscutting relations are not so clear, but the relative timing of set 3 is constrained by infill composed of the late sulphosalt-gold association of the stage 3 paragenesis. 


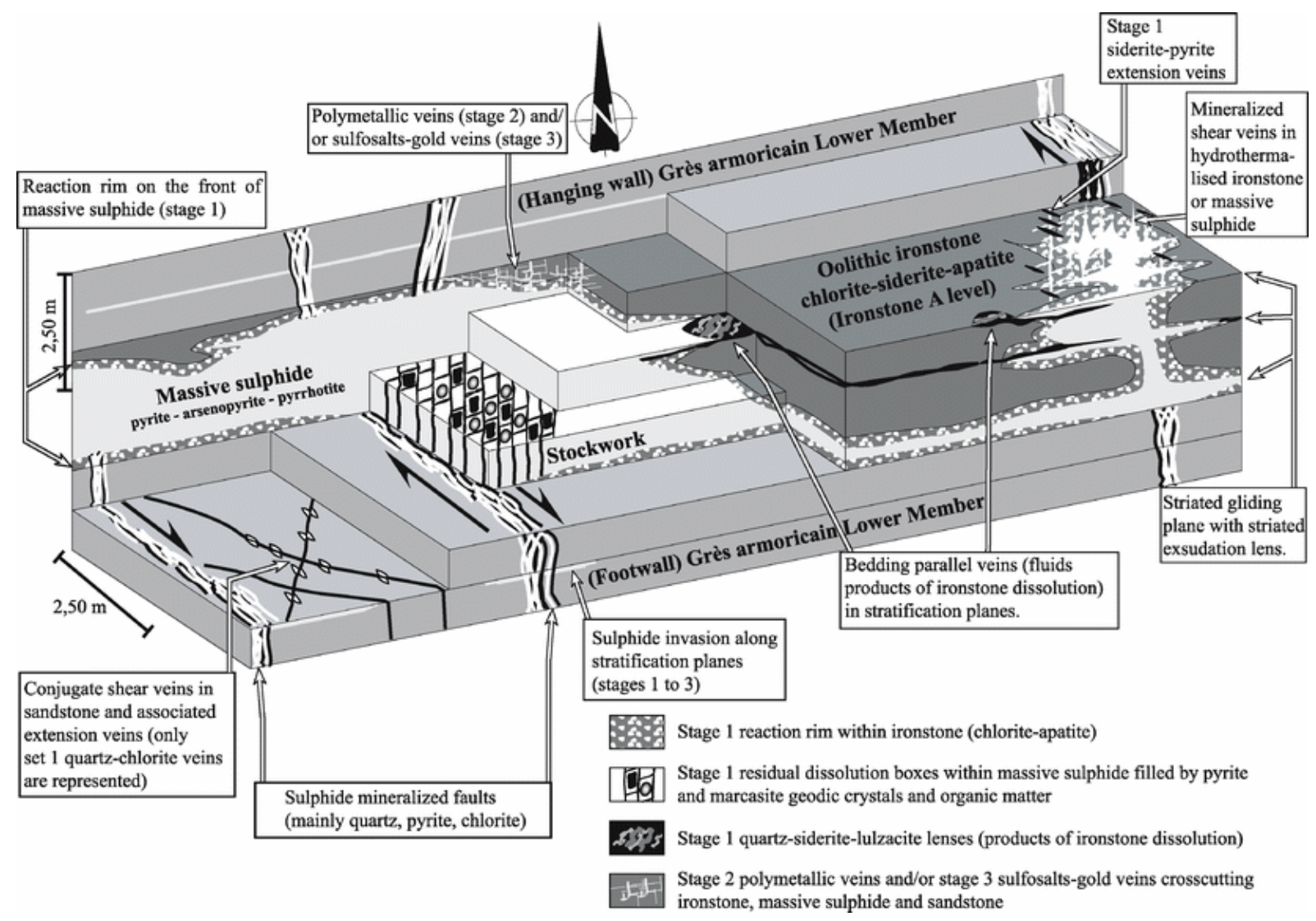

Fig. 8 Three-dimensional synthetic block diagram of hydrothermal alteration in the OIH from non-altered to massive sulphide facies. Relationships with mineralizing fractures are represented 


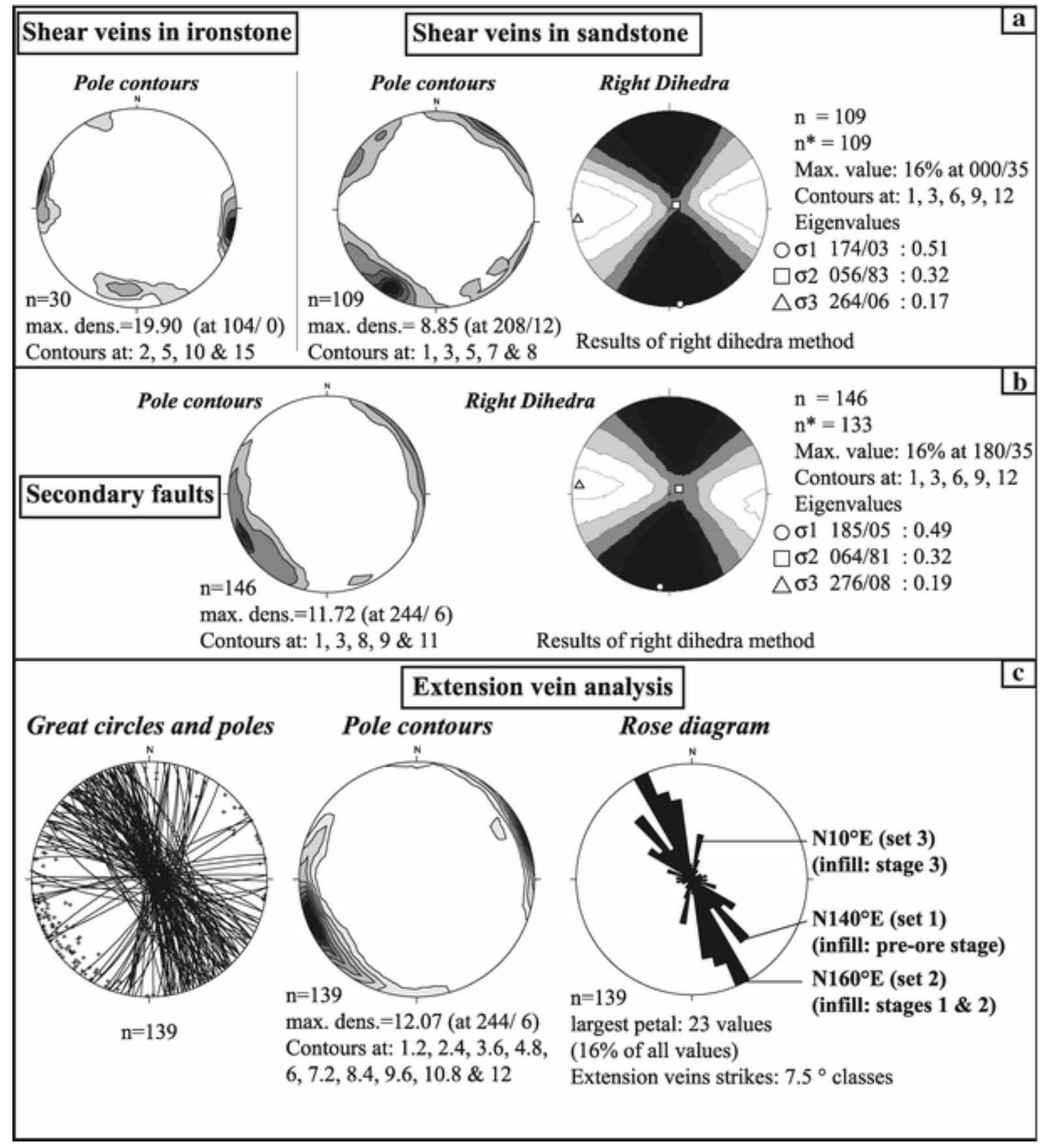

Fig. 9 a Density and right dihedra stereograms calculated from shear veins affecting OIH and surrounding sandstones. b Density and right dihedra stereograms calculated from secondary faults. c Separation of extension veins sets and their respective infills (stereograms are equal area, lower hemisphere) 


\section{Geothermometry}

\section{Chlorite geothermometer}

In the Saint-Aubin-des-Châteaux mineralisation, four main chlorite generations can be distinguished: (1) diagenetic/metamorphic chlorite present in non-altered OIH (Fig. 5a); (2) hydrothermal chlorite related to stage 1 and present in massive sulphide lenses and their reaction rims (Fig. 6b,c and e); (3) hydrothermal chlorite found in stage 2 veins (Fig. 6f) and (4) chlorite from stage 3 sulphosalt- and gold-bearing veins.

Chlorite from each generation is chamosite (see EPMA; Table 4), according to the classification of Bailey (1980).

Table 4 Average electron microprobe analyses (wt\%) and corresponding structural formulae (a.p.f.u.) of chlorite (stages 1 to 3 ) from ironstone A-layer and quartz veins

\begin{tabular}{|c|c|c|c|c|c|c|c|c|c|}
\hline Stage & Pre-ore & Stage 1 & Stage 1 & Stage 1 & Stage 1 & Stage 1 & Stage 2 & Stage 2 & Stage 3 \\
\hline \multirow[t]{2}{*}{ Localisation } & OIH & OIH & OIH & OIH & OIH & OIH & OIH & \multirow[t]{2}{*}{ Sandstone } & \multirow[t]{2}{*}{ Sandstone } \\
\hline & Non-altered & \multicolumn{6}{|c|}{ Hydrothermally altered ironstone facies } & & \\
\hline Facies & $\begin{array}{l}\text { Oolitic } \\
\text { siderite- } \\
\text { chlorite } \\
\text { facies }\end{array}$ & $\begin{array}{l}\text { Chl-Py } \\
\text { facies } \\
\text { (oolites } \\
\text { ghosts) }\end{array}$ & $\begin{array}{l}\text { Oolitic } \\
\text { chloritic } \\
\text { facies }\end{array}$ & $\begin{array}{l}\text { Reaction } \\
\text { rim Chl- } \\
\text { Ap facies }\end{array}$ & $\begin{array}{l}\text { Reaction } \\
\text { rim Chl- } \\
\text { (Ap) facies }\end{array}$ & $\begin{array}{l}\text { Massive } \\
\text { sulphide } \\
\text { lenses }\end{array}$ & $\begin{array}{l}\text { Border of } \\
\text { sulphide } \\
\text { vein }\end{array}$ & $\begin{array}{l}\text { Polymetallic } \\
\text { quartz vein }\end{array}$ & $\begin{array}{l}\text { Sulphosalt- } \\
\text { gold quartz } \\
\text { vein }\end{array}$ \\
\hline $\begin{array}{l}\text { Chl } \\
\text { generation }\end{array}$ & 1 & 2 & 2 & 2 & 2 & 2 & 3 & 3 & 4 \\
\hline $\begin{array}{l}\text { Chlorite } \\
\text { type }\end{array}$ & Green Chl & Green Chl & Green Chl & Red Chl & Green Chl & Red Chl & Red Chl & Green Chl & Green Chl \\
\hline $\mathrm{FeO}$ & 40.12 & 40.05 & 40.00 & 39.09 & 37.98 & 40.71 & 40.30 & 38.79 & 42.34 \\
\hline $\mathrm{MnO}$ & 0.11 & 0.07 & 0.06 & 0.06 & 0.17 & 0.11 & 0.10 & 0.29 & 0.15 \\
\hline $\mathrm{MgO}$ & 1.28 & 1.29 & 1.14 & 1.77 & 1.87 & 1.12 & 1.35 & 2.18 & 1.37 \\
\hline $\mathrm{CaO}$ & 0.01 & 0.02 & 0.08 & 0.01 & 0.09 & 0.02 & 0.02 & 0.01 & 0.02 \\
\hline $\mathrm{BaO}$ & - & 0.09 & 0.05 & 0.05 & 0.07 & 0.07 & - & - & - \\
\hline $\mathrm{ZnO}$ & - & 0.12 & 0.02 & 0.03 & 0.07 & 0.08 & - & - & - \\
\hline $\mathrm{CuO}$ & - & 0.04 & nd & 0.02 & 0.02 & 0.02 & - & - & - \\
\hline $\mathrm{Al}_{2} \mathrm{O}_{3}$ & 24.25 & 27.69 & 26.48 & 26.66 & 26.20 & 25.50 & 25.05 & 25.39 & 22.58 \\
\hline $\mathrm{V}_{2} \mathrm{O}_{3}$ & 0.25 & 0.47 & 0.10 & 0.82 & 0.84 & 0.84 & 0.24 & 0.02 & 0.03 \\
\hline $\mathrm{K}_{2} \mathrm{O}$ & 0.01 & - & - & - & - & - & 0.01 & nd & nd \\
\hline $\mathrm{Na}_{2} \mathrm{O}$ & 0.02 & - & - & - & - & - & 0.01 & 0.01 & 0.01 \\
\hline $\mathrm{SiO}_{2}$ & 21.05 & 19.54 & 19.87 & 20.46 & 20.93 & 20.57 & 20.93 & 21.41 & 21.79 \\
\hline $\mathrm{TiO}_{2}$ & 0.02 & 0.02 & 0.03 & 0.01 & 0.02 & 0.02 & 0.01 & 0.01 & 0.02 \\
\hline $\mathrm{F}$ & 0.11 & - & - & - & - & - & 0.03 & 0.06 & 0.04 \\
\hline $\mathrm{Cl}$ & 0.01 & - & - & - & - & - & 0.01 & nd & 0.01 \\
\hline \multirow[t]{2}{*}{ Total } & 87.24 & 89.39 & 87.85 & 88.97 & 88.26 & 89.06 & 88.07 & 88.17 & 88.35 \\
\hline & & \multicolumn{6}{|c|}{ Number of atoms on the basis of 28 oxygens } & & \\
\hline $\mathrm{Fe}^{\mathrm{a}}$ & 7.78 & 7.55 & 7.67 & 7.35 & 7.17 & 7.74 & 7.72 & 7.35 & 8.19 \\
\hline $\mathrm{Mn}$ & 0.02 & 0.01 & 0.01 & 0.01 & 0.03 & 0.02 & 0.02 & 0.05 & 0.03 \\
\hline $\mathrm{Mg}$ & 0.44 & 0.43 & 0.39 & 0.59 & 0.63 & 0.38 & 0.46 & 0.74 & 0.47 \\
\hline $\mathrm{Ca}$ & 0.00 & 0.00 & 0.02 & 0.00 & 0.02 & 0.00 & 0.01 & 0.00 & 0.00 \\
\hline $\mathrm{Ba}$ & - & 0.01 & 0.00 & 0.00 & 0.01 & 0.01 & - & - & - \\
\hline $\mathrm{Zn}$ & - & 0.02 & 0.00 & 0.01 & 0.01 & 0.01 & - & - & - \\
\hline $\mathrm{Cu}$ & - & 0.01 & 0.00 & 0.00 & 0.00 & 0.00 & - & - & - \\
\hline $\mathrm{Al}^{\mathrm{VI}}$ & 3.52 & 3.76 & 3.72 & 3.67 & 3.69 & 3.51 & 3.56 & 3.63 & 3.19 \\
\hline V & 0.05 & 0.09 & 0.02 & 0.15 & 0.15 & 0.15 & 0.04 & 0.00 & 0.01 \\
\hline Vac & 0.19 & 0.12 & 0.15 & 0.21 & 0.28 & 0.17 & 0.19 & 0.22 & 0.11 \\
\hline
\end{tabular}




\begin{tabular}{|c|c|c|c|c|c|c|c|c|c|}
\hline Stage & Pre-ore & Stage 1 & Stage 1 & Stage 1 & Stage 1 & Stage 1 & Stage 2 & Stage 2 & Stage 3 \\
\hline \multirow[t]{2}{*}{ Localisation } & OIH & OIH & OIH & OIH & OIH & OIH & OIH & \multirow[t]{2}{*}{ Sandstone } & \multirow[t]{2}{*}{ Sandstone } \\
\hline & Non-altered & \multicolumn{6}{|c|}{ Hydrothermally altered ironstone facies } & & \\
\hline Facies & $\begin{array}{l}\text { Oolitic } \\
\text { siderite- } \\
\text { chlorite } \\
\text { facies }\end{array}$ & $\begin{array}{l}\text { Chl-Py } \\
\text { facies } \\
\text { (oolites } \\
\text { ghosts) }\end{array}$ & $\begin{array}{l}\text { Oolitic } \\
\text { chloritic } \\
\text { facies }\end{array}$ & $\begin{array}{l}\text { Reaction } \\
\text { rim Chl- } \\
\text { Ap facies }\end{array}$ & $\begin{array}{l}\text { Reaction } \\
\text { rim Chl- } \\
\text { (Ap) facies }\end{array}$ & $\begin{array}{l}\text { Massive } \\
\text { sulphide } \\
\text { lenses }\end{array}$ & $\begin{array}{l}\text { Border of } \\
\text { sulphide } \\
\text { vein }\end{array}$ & $\begin{array}{l}\text { Polymetallic } \\
\text { quartz vein }\end{array}$ & $\begin{array}{l}\text { Sulphosalt- } \\
\text { gold quartz } \\
\text { vein }\end{array}$ \\
\hline $\begin{array}{l}\text { Chl } \\
\text { generation }\end{array}$ & 1 & 2 & 2 & 2 & 2 & 2 & 3 & 3 & 4 \\
\hline $\begin{array}{l}\text { Chlorite } \\
\text { type }\end{array}$ & Green Chl & Green Chl & Green Chl & Red Chl & Green Chl & Red Chl & Red Chl & Green Chl & Green Chl \\
\hline K & 0.00 & - & - & - & - & - & 0.00 & 0.00 & 0.00 \\
\hline $\mathrm{Na}$ & 0.01 & - & - & - & - & - & 0.01 & 0.01 & 0.00 \\
\hline $\mathrm{Si}$ & 4.88 & 4.40 & 4.56 & 4.60 & 4.72 & 4.68 & 4.79 & 4.85 & 5.04 \\
\hline $\mathrm{Ti}$ & 0.00 & 0.00 & 0.01 & 0.00 & 0.00 & 0.00 & 0.00 & 0.00 & 0.00 \\
\hline $\mathrm{Al}^{\mathrm{IV}}$ & 3.11 & 3.59 & 3.43 & 3.40 & 3.27 & 3.32 & 3.20 & 3.15 & 2.96 \\
\hline $\mathrm{OH}$ & 15.92 & 16.00 & 16.00 & 16.00 & 16.00 & 16.00 & 15.98 & 15.96 & 15.97 \\
\hline $\mathrm{F}$ & 0.08 & - & - & - & - & - & 0.02 & 0.04 & 0.03 \\
\hline $\mathrm{Cl}$ & 0.00 & - & - & - & - & - & 0.00 & 0.00 & 0.00 \\
\hline$\Sigma \mathrm{Fe}^{\mathrm{a}} / \Sigma \mathrm{R}^{2+}$ & 0.94 & 0.94 & 0.95 & 0.92 & 0.91 & 0.95 & 0.94 & 0.90 & 0.94 \\
\hline$T\left({ }^{\circ} \mathrm{C}\right)$ & $292 \pm 10$ & $343 \pm 21$ & $325 \pm 20$ & $324 \pm 12$ & $312 \pm 9$ & $313 \pm 10$ & $302 \pm 10$ & $299 \pm 8$ & $275 \pm 9$ \\
\hline
\end{tabular}

Mineral compositions were obtained using a CAMECA CAMEBAX (common laboratory: BRGM-CNRSOrleans University). Operating conditions were $15 \mathrm{kV}$ accelerating voltage and $12 \mathrm{nA}$-beam current, using the following X-ray lines and standards: $\mathrm{Fe} \mathrm{K} \alpha$ (synthetic $\mathrm{Fe}_{2} \mathrm{O}_{3}$ ), $\mathrm{Mn} \mathrm{K \alpha}$ (synthetic $\mathrm{MnTiO}_{3}$ ), $\mathrm{Mg} \mathrm{K \alpha}$ (olivine), Ca $\mathrm{K} \alpha$ (andradite), $\mathrm{Ba} \mathrm{L} \alpha$ (barite), $\mathrm{Zn} \mathrm{K} \alpha$ (sphalerite), $\mathrm{Cu} \mathrm{K} \alpha$ (copper metal), $\mathrm{Al} \mathrm{K} \alpha\left(\mathrm{Al}_{2} \mathrm{O}_{3}\right), \mathrm{V} \mathrm{K} \alpha$ (vanadinite), $\mathrm{K}$ $\mathrm{K} \alpha$ (orthoclase), $\mathrm{Na} \mathrm{K} \alpha$ (albite), $\mathrm{Si} \mathrm{K} \alpha$ (albite), $\mathrm{Ti} \mathrm{K} \alpha$ (synthetic $\mathrm{MnTiO}_{3}$ ), F K $\alpha$ (topaz) and $\mathrm{Cl} \mathrm{K \alpha}$ (vanadinite). $n d$ below detection limit; $(-)$ is not analyzed

${ }^{\mathrm{a}}$ Total $\mathrm{Fe}$ as $\mathrm{FeO}$

As numerous authors have noted a strong positive correlation between the $\mathrm{Al}^{\mathrm{IV}}$ content of chlorite and temperature, numerous geothermometers have been developed (Cathelineau and Nieva 1985 modified by Cathelineau 1988; Kranidiotis and MacLean 1987; Hillier and Velde 1991; Jowett 1991; Zang and Fyfe 1995; Xie et al. 1997). The differences between these geothermometers depend on the effect of $\mathrm{Mg}+\mathrm{Fe}$ content, which increases with temperature (McDowell and Elders 1980), and the degree of control of the chlorite composition by host rocks. Due to the high $\mathrm{Fe} / \Sigma R^{2+}$ ratios in our samples, which vary from 0.89 to 0.96 , it is necessary to correct $\mathrm{Al}^{\mathrm{IV}}$ using the equation proposed by Zang and Fyfe (1995). Thus, we have used the equation from Cathelineau and Nieva (1985) modified by Zang and Fyfe (1995): $T\left({ }^{\circ} \mathrm{C}\right)=106.2 \times\left(\mathrm{Al}^{\mathrm{IV}}\right.$ measured $-0.88[\mathrm{Fe} /(\mathrm{Fe}+\mathrm{Mg})-0.34]+17.5$. This equation has been previously used for temperature calculation on chamosite from Lower Ordovician ironstone in Spain (Fernández and Moro 1998) and compared with success to the chlorite geothermometer of Walshe (1986).

The calculated temperature for the first chlorite generation (non-altered facies of $\mathrm{OIH}$ ) is $292 \pm 10^{\circ} \mathrm{C}$ (Table 4). This temperature is consistent with the regional low-grade metamorphism. A maximum of $250-300^{\circ} \mathrm{C}$ is obtained by vitrinite reflectance in the AngersTraveusot Formation (Donnot et al. 1973), chloritoid-bearing schists indicate lower greenschist facies conditions for the same formation (Le Corre 1969), and epizonal metamorphism is indicated by illite crystallinity (Le Corre 1975). Thus, the peak of regional metamorphism is of very low greenschist facies (i.e. $\sim 300^{\circ} \mathrm{C}$ ). Gross calculation of maximum overburden yields a peak pressure around $1.5 \mathrm{kbar}$. 
The second generation of chlorite has yielded high temperatures from $312 \pm 9^{\circ} \mathrm{C}$ up to $343 \pm 21^{\circ} \mathrm{C}$ (Table 4). This suggests an input of hot hydrothermal fluids during the massive sulphidation of the $\mathrm{OIH}$ (stage 1).

Stages 2 and 3 have yielded $302 \pm 10$ to $299 \pm 8$ and $275 \pm 9^{\circ} \mathrm{C}$, respectively. This temperature decrease relative to stage 1 is consistent with the paragenetic evolution, considering that sulphosalts are often found in "low" temperature deposits.

\section{Arsenopyrite geothermometer}

EPMA (Table 3) reveal the presence in arsenopyrite of cobalt $(0.67 \pm 0.36$ at.\%) as well as traces of antimony ( 0 to 0.06 at.\%) and nickel ( 0 to 0.04 at.\%). The structural formula calculated on the basis of a total of three atoms is

\section{$\left(\mathrm{Fe}_{0.97} \mathrm{Co}_{00 \mathrm{O}}\right)_{5-0.99} \mathrm{As} \mathrm{S}_{0.96} \mathrm{~S}_{1.05}$}

The composition of arsenopyrite is relatively homogeneous with a mean content of $31.97 \pm 0.36$ at. $\%$ As $(n=53)$. It is assumed that the beginning of crystallisation took place at the pyrite-pyrrhotite buffer, as pyrrhotite is observed as inclusions in arsenopyrite. According to Sundblad et al. (1984), trace elements like $\mathrm{Co}, \mathrm{Ni}$ or Sb with concentrations of about $0.2 \mathrm{wt} \%$ can disturb the arsenopyrite geothermometer because of the correlation observed between As-Co, As-Ni and As-Sb. However, Bril et al. (1981) have demonstrated the independence of the $\mathrm{Sb}$ content on the $[(\mathrm{As}+\mathrm{Sb}) / \mathrm{S}]$ ratio in Hercynian arsenopyrites. In the same way, our data show the independence of the Co content on the $[(\mathrm{Fe}+\mathrm{Co}) / \mathrm{S}]$ ratio in arsenopyrite and no correlation between $\mathrm{As}-\mathrm{Co}, \mathrm{As}-\mathrm{Ni}$ and $\mathrm{As}-\mathrm{Sb}$ is evident in our data. Thus, despite values which range from 0 to $0.75 \mathrm{wt} \%$ for $\mathrm{Co}$ and 0 to $0.28 \mathrm{wt} \%$ for $\mathrm{Sb}$, the As content in arsenopyrite does not appear to be disturbed. Moreover, in our case, $\mathrm{Co}+\mathrm{Ni}+\mathrm{Sb}$ is equal to $0.88 \mathrm{wt} \%$, which is lower than the value of $1 \mathrm{wt} \%$ as recommended by Kretschmar and Scott (1976). According to the arsenopyrite geothermometer of these authors modified by Sharp et al. (1985), a temperature of crystallisation between 390 and $480^{\circ} \mathrm{C}$ can be calculated for stage 1 , with a sulphur fugacity between $10^{-5}$ and $10^{-8} \mathrm{~atm}$.

This temperature range is higher than the maximum temperature obtained using the chlorite geothermometer $\left(312 \pm 9\right.$ to $\left.343 \pm 21^{\circ} \mathrm{C}\right)$. Many authors (Bril 1982, 1985; Maurel Palacin 1985; Almeida and Noronha 1988) have compared temperatures given by arsenopyrite analysis and fluid inclusion studies and have shown the tendency of the arsenopyrite geothermometer to overestimate the temperature. Despite its inaccuracy, this geothermometer is consistent with a temperature above $300^{\circ} \mathrm{C}$ for the stage 1 . Moreover, the temperature peak of the hydrothermal fluid is likely recorded by early sulphides (e.g. arsenopyrite) rather than chlorite, which more likely reflects temperature equilibrium between host rock and fluid. Thus, we infer a maximum temperature of about $350-390^{\circ} \mathrm{C}$ for the stage 1 , which is more reliable than the arsenopyrite-based estimate. 


\section{Lead isotopes}

\section{Sampling and analysis}

Six samples of galena have been collected from veins in the OIH (SA9, SADC18), and from extension veins (SADC72A), veins (SADC74), shear veins (E3-E5) and bedding-parallel veins (SADC73) in sandstone. This allows the identification of lead and associated metal sources for stages 2 and 3 , given that the massive sulphidation stage 1 is $\mathrm{Pb}$-free.

Samples have been picked from galena crystals under the binocular. We used the sample preparation protocol described by Marcoux (1987). Lead isotope compositions have been analysed at the Isotopic Geochemistry Laboratory of Geosciences, Rennes 1 University (France) and measured with a multicollector Finnigan Mat 262 mass spectrometre. The internal analytical error $\delta_{\mathrm{m}}$ is about 0.015 for ${ }^{206} \mathrm{~Pb} /{ }^{204} \mathrm{~Pb}(\alpha)$ and ${ }^{207} \mathrm{~Pb} /{ }^{204} \mathrm{~Pb}(\beta)$ and about 0.040 for ${ }^{208} \mathrm{~Pb} /{ }^{204} \mathrm{~Pb}(\gamma)$ ratio. A fractionation correction factor, calculated by repeated analysis of NBS 981, 982 and 983, was applied to each measurement. External reproducibility is about $1 \%$.

\section{Results}

The data (Table 5) have been reported on $\mathrm{Pb}-\mathrm{Pb}$ diagrams and compared with lead isotope data available in mineral deposits of the Armorican Massif (Marcoux 1987; Chauris and Marcoux 1994; Fig. 10). Lead isotope compositions of galena from Saint-Aubin-desChâteaux are quite constant, regardless of sample type, with values ranging from 18.043 to 18.096 for ${ }^{206} \mathrm{~Pb} /{ }^{204} \mathrm{~Pb}, 15.646$ to 15.664 for ${ }^{207} \mathrm{~Pb} /{ }^{204} \mathrm{~Pb}$ and 38.278 to 38.397 for ${ }^{208} \mathrm{~Pb} /{ }^{204} \mathrm{~Pb}$. Thus, the stage 2 lead isotopic composition is identical for veins affecting OIH and veins in sandstone far from $\mathrm{OIH}$.

Table 5 Lead isotopic compositions of galena from the Saint-Aubin-des-Châteaux mineralisation

\begin{tabular}{|c|c|c|c|c|c|c|c|}
\hline \multirow{2}{*}{ Sample } & \multirow{2}{*}{ Sample designation } & \multirow{2}{*}{ Location } & \multirow{2}{*}{ Paragenesis } & \multirow{2}{*}{ Stage } & \multirow{2}{*}{\begin{tabular}{|l|}
${ }^{206} \mathrm{~Pb} /{ }^{204} \mathrm{~Pb}$ \\
\pm 0.015 \\
\end{tabular}} & \multirow{2}{*}{\begin{tabular}{|l|}
${ }^{207} \mathrm{~Pb} /{ }^{204} \mathrm{~Pb}$ \\
\pm 0.015 \\
\end{tabular}} & \multirow{2}{*}{\begin{tabular}{|l}
${ }^{208} \mathrm{~Pb} /{ }^{204} \mathrm{~Pb}$ \\
$\mathbf{0 . 0 1 5}$
\end{tabular}} \\
\hline & & & & & & & \\
\hline E3-E5 & Dextral shear vein & $\begin{array}{l}\text { SE pit no. } \\
2\end{array}$ & Qtz, Py, Chl, Gn & 2 & 18.096 & 15.646 & 38.397 \\
\hline SA9 & $\begin{array}{l}\text { Polymetallic apatite-bearing veins within } \\
\text { hydrothermally altered ironstone }\end{array}$ & $\begin{array}{l}\text { SW pit no. } \\
2\end{array}$ & $\begin{array}{l}\text { Py, Sp, Ccp, Gn, Chl, } \\
\text { Ap }\end{array}$ & 2 & 18.062 & 15.653 & 38.328 \\
\hline SADC18 & $\begin{array}{l}\text { Polymetallic veins crosscutting hydrothermally } \\
\text { altered ironstone }\end{array}$ & $\begin{array}{l}\text { SW pit no. } \\
2\end{array}$ & $\begin{array}{l}\text { Qtz, Py, Sp, Ccp, Gn, } \\
\text { Ap, Chl }\end{array}$ & 2 & 18.067 & 15.653 & 38.306 \\
\hline SADC72A & Extension vein & $\begin{array}{lll}\text { W } & \text { pit no. } \\
1 & \end{array}$ & $\begin{array}{l}\text { Qtz, Py, Sp, Gn, Ccp, } \\
\text { Chl }\end{array}$ & 2 & 18.051 & 15.664 & 38.315 \\
\hline SADC73 & $\begin{array}{l}\text { Parallel bedding vein at the ironstone A-level } \\
\text { footwall }\end{array}$ & $\begin{array}{lll}\text { W } & \text { pit no. } \\
1 & & \end{array}$ & $\begin{array}{l}\text { Qtz, Sd, Ap, Dol, Gn, } \\
\text { Py }\end{array}$ & 2 & 18.083 & 15.660 & 38.350 \\
\hline SADC74 & $\begin{array}{l}\text { Sulphosalt vein at the ironstone A-level } \\
\text { hanging wall }\end{array}$ & $\begin{array}{l}\text { W pit no. } \\
1\end{array}$ & $\begin{array}{l}\text { Qtz, Chl, Tur, Gn, } \\
\text { Blg, El }\end{array}$ & 3 & 18.043 & 15.652 & 38.278 \\
\hline
\end{tabular}

Qtz quartz; Chl chlorite; $A p$ apatite; $S d$ siderite; Dol dolomite; Tur tourmaline; Py pyrite; $S p$ sphalerite; Ccp chalcopyrite; $G n$ galena; Blg boulangerite; El electrum

The massive sulphidation process is related to the $\mathrm{Pb}$-free Fe-As stage 1. Nevertheless, galena from stage 2 is present in quartz-siderite-lulzacite bedding-parallel veins produced during stage 1 (Table 2). The lead isotopic composition of galena from one of these veins (SADC 73) is similar to that of the other samples from stage 2. This result suggests that stage 2 fluids have percolated through the stage 1 bedding-parallel veins. 
Within analytical error, the lead isotopic composition of galena from galena-sulphosalt-gold veins (stage 3 ) is also similar to galena from stage 2 . This suggests a unique source for $\mathrm{Pb}$ during stages 2 and 3 . This conclusion likely holds for other metals, including gold.

The lead isotopic compositions of a Neo-Proterozoic metapelite have been calculated and plotted in $\mathrm{Pb}-\mathrm{Pb}$ diagrams at various ages ranging from 600 to $250 \mathrm{Ma}$ (Fig. 10). The high ${ }^{208} \mathrm{~Pb} /{ }^{204} \mathrm{~Pb}$ ratios of the Saint-Aubin-des-Châteaux samples relative to the ${ }^{206} \mathrm{~Pb} /{ }^{204} \mathrm{~Pb}$ ratio indicate a contribution of old continental crust to the lead budget. This suggests that the underlying Neo-Proterozoic basement (Fig. 2b) is a likely metal source. Consequently, gold might be leached from the Neo-Proterozoic basement too.

$\mathrm{On} \mathrm{Pb}-\mathrm{Pb}$ diagrams (Fig. 10), two main fields of vein-type mineralisation related to the Hercynian orogeny are plotted. The first field gathers "low-temperature deposits" $(\mathrm{Pb}-\mathrm{Zn}, \mathrm{U}-$ $\mathrm{Pb}$ and $\mathrm{Sb}$ vein deposits), whereas the second one represents "high-temperature deposits" (As $\pm \mathrm{Sn} \pm \mathrm{W}$ followed by polymetallic stage $\mathrm{Pb} \pm \mathrm{Zn} \pm \mathrm{Cu}$ and late stage $\pm \mathrm{Au} \pm \mathrm{Sb} \pm \mathrm{Bi}$ ). The SaintAubin-des-Châteaux samples clearly plot close to the "high-temperature deposits" field, consistent with our temperature estimates. The ages of the first type of deposits are poorly constrained, but are believed to be Carboniferous to Permian in age (Chauris and Marcoux 1994). Conversely, the ages of "high-temperature deposits" seem to be older (i.e. older than $300 \mathrm{Ma})$.

In addition, two other deposits located in the vicinity of Saint-Aubin-des-Châteaux, appear anomalous when compared to the defined fields and are close to the Saint-Aubin-desChâteaux samples. These are the Le Semnon As-Sb-Au deposit (500 t Sb at 6\% Sb and $7 \mathrm{~g} / \mathrm{t}$ $\mathrm{Au}$, Méloux et al. 1979; Chauris et al. 1985) and the La-Chapelle-Saint-Melaine As-Pb-Cu$\mathrm{Zn}-\mathrm{Sb}$ deposit (Kerforne 1923). Similar mineralogy, paragenetic sequences and structural settings lead us to suggest a common Neo-Proterozoic partial source of lead for these three neighbouring deposits. 

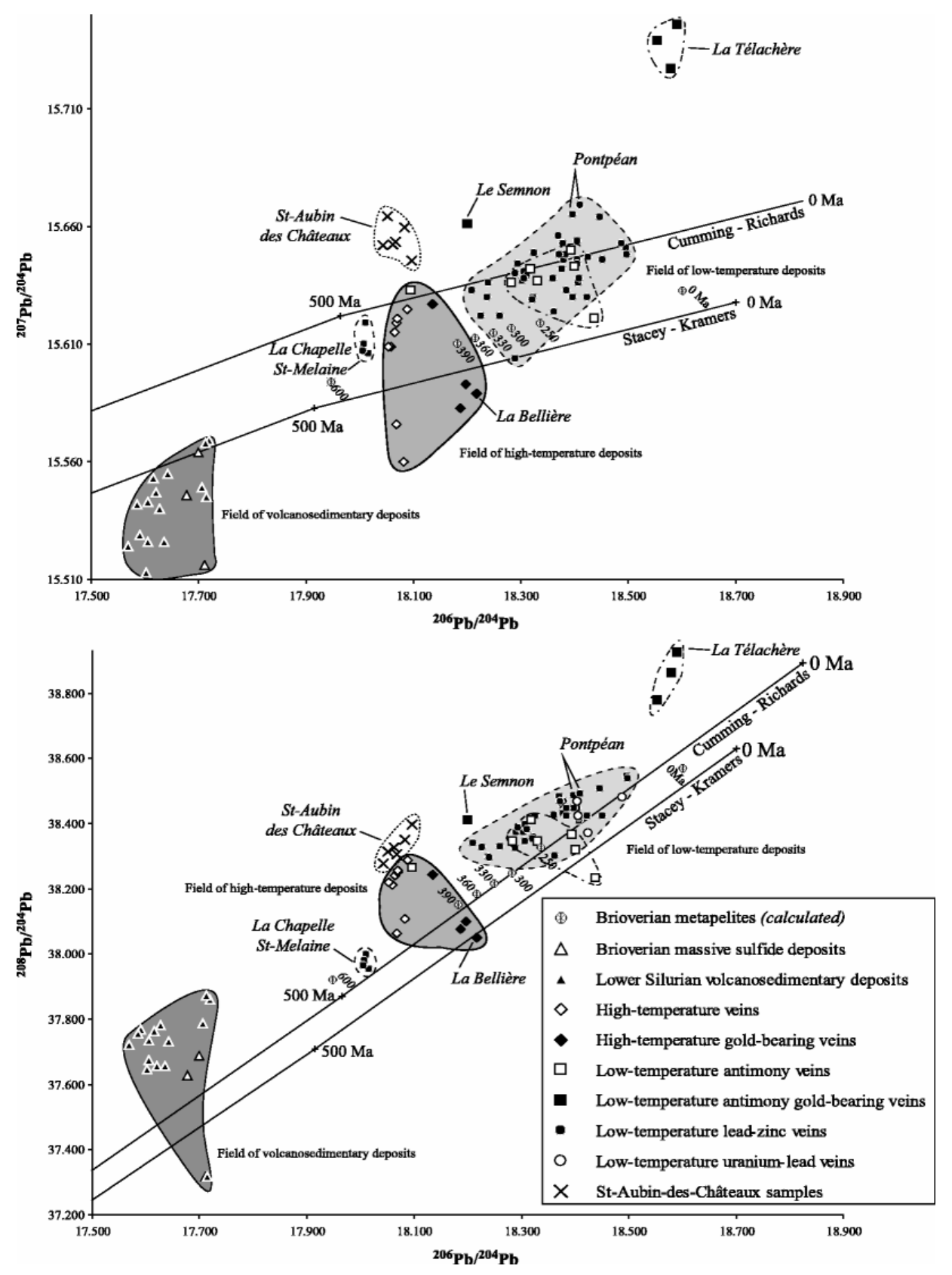

Fig. 10 Lead isotope composition of the Saint-Aubin-des-Châteaux mineralization compared with available published data (Marcoux 1987; Oh et al. 1989) for the Armorican massif (except those from the North Armorican Domain); Lead evolution curves (plain lines) after Stacey and Kramers (1975) and after Cumming and Richards (1975); Lead isotope composition of Brioverian (Neo-Proterozoic) metapelites from Marcoux (1987). Ages (in italics) at 600, 390, 360, 330, 300 and 250 Ma have been calculated; Neo-Proterozoic massive sulphide deposits:Rouez, Kerham; Lower Silurian volcanosedimentary deposits: Fégréac, La Comterie, La HaieClaire, Bois d'Ardennes, Belligné, Bois-Souchard, Pannecé, Le Plessis, La Priancière, Le Retaud; Hightemperature veins: Quelornet $\mathrm{As}-(\mathrm{Pb})$, La Chauvière $\mathrm{As}-\mathrm{Pb}-\mathrm{Sb}$, La Rousselière $\mathrm{Sn}-\mathrm{As}-\mathrm{Pb}-\mathrm{Zn}$, Saint-Herblon 1 $\mathrm{W}-\mathrm{As}-\mathrm{Pb}$;High-temperature gold-bearing veins: La Bellière $\mathrm{As}-\mathrm{Zn}-\mathrm{Pb}-\mathrm{Cu}-\mathrm{Au}$, La Roche-Balue $\mathrm{W}-\mathrm{As}-\mathrm{Pb}-$ $\mathrm{Au}$, Bazoges As-Pb-Bi-Au; Antimony veins: Beg-ar-Galez, Bestrée, Ty Gardien, La Maindronnière, SaintHerblon 2; Antimony gold-bearing veins: La Télachère, Le Semnon; Lead-zinc veins:Pors Loubous, Pointe de Plogoff, Pointe Ty Deved, Pointe du Castel, Pors Tars, Pors Loëdec, Pointe de Lesven, Pointe de Beuzec, Kerhuo, Plélauff, Trégornan, Locrio, Saint-Fiacre, Saint-Modé, Plumelin, La Telhaie, Pontpéan, La ChapelleSaint-Melaine, Crossac, Le Sem, Le Mérel, Le Bodéo, Plusquellec, Carnoët, Huelgoat, Poullaouen, Le Pouillou); Uranium-lead veins: Le Vouëdec, La Villeneuve, Quistiave. The fields of volcanosedimentary deposits and those of high- and low-temperature deposits are contoured and filled in grey half-tone 


\section{Interpretation and model}

\section{Deformation and fluid flow}

Potential shear veins corresponding to a $\mathrm{N} 140^{\circ} \mathrm{E}$ shortening (Z1) direction are weakly developed in the quarry (Fig. 9). On the other hand, dextral rotation of shortening directions from $\mathrm{N} 160^{\circ} \mathrm{E}(\mathrm{Z} 2)$ to $\mathrm{N} 10^{\circ} \mathrm{E}(\mathrm{Z} 3)$ is compatible with the observed fault-shear vein strikes and explains the strike variation. The $\mathrm{N}-\mathrm{S}$ shortening direction obtained from the Right Dihedra method corresponds to the mean value between $\mathrm{Z} 2$ and $\mathrm{Z} 3$. Thus, the major part of shear veins and faults formed during clockwise rotation of horizontal shortening from Z2 to Z3. Within OIH, shear veins are responsible for the formation of boxworks located precisely along strike-slip fault traces (Fig. 8). The shear veins are compatible with Z1 (Fig. 9a) but are typically filled with sulphides and polymetallic parageneses characteristic of sets 2 and 3 . We interpret these shear veins affecting OIH as a secondary fault system initiated during Z1 shortening, reactivated and filled with sulphides during Z2 and Z3 shortening. The reactivation of unfavourably oriented fractures can indeed be enhanced by high fluid pressure (Sibson 1990). The peculiar rheology and permeability of OIH might explain the lack of boxwork in surrounding sandstone.

Extension veins in the quarry record three successive increments of pure strike-slip deformation. The clockwise rotation of incremental shortening directions confirms that the Saint-Aubin-des-Châteaux area was affected by a non-coaxial dextral deformation linked to the Hercynian NBSASZ.

All data suggest that deformation was coeval with fluid flow and controlled the development of hydrothermal alteration within OIH. Massive sulphidation (stage 1) within OIH was coeval with the circulation of hydrothermal fluids along active wrench faults. The characteristics of the OIH (rheology, permeability and chemistry) allowed this stratigraphic level to act as a trap for the elements carried by the fluids. The fractures and faults hosting the polymetallic stages 2 and 3 are strictly compatible with the deformation pattern during the massive sulphidation stage 1. Major strike-slip faults are clearly identified as main drains for these fluids.

\section{Model}

Based on the structural, petrological and geochemical data presented above, we propose an evolutive model of formation, integrating tectonics, fluid flow and possible metal source (Fig. 11).

The first increment of deformation corresponds to a $\mathrm{N} 140^{\circ} \mathrm{E}$ shortening (Z1) direction responsible for development of pre-ore quartz tension gashes (set 1), homogeneously distributed both within sandstone and $\mathrm{OIH}$. The nature and origin of fluids responsible for this quartz deposition are not constrained, but are likely related to dehydratation reactions during the very low-grade metamorphism affecting this area. 


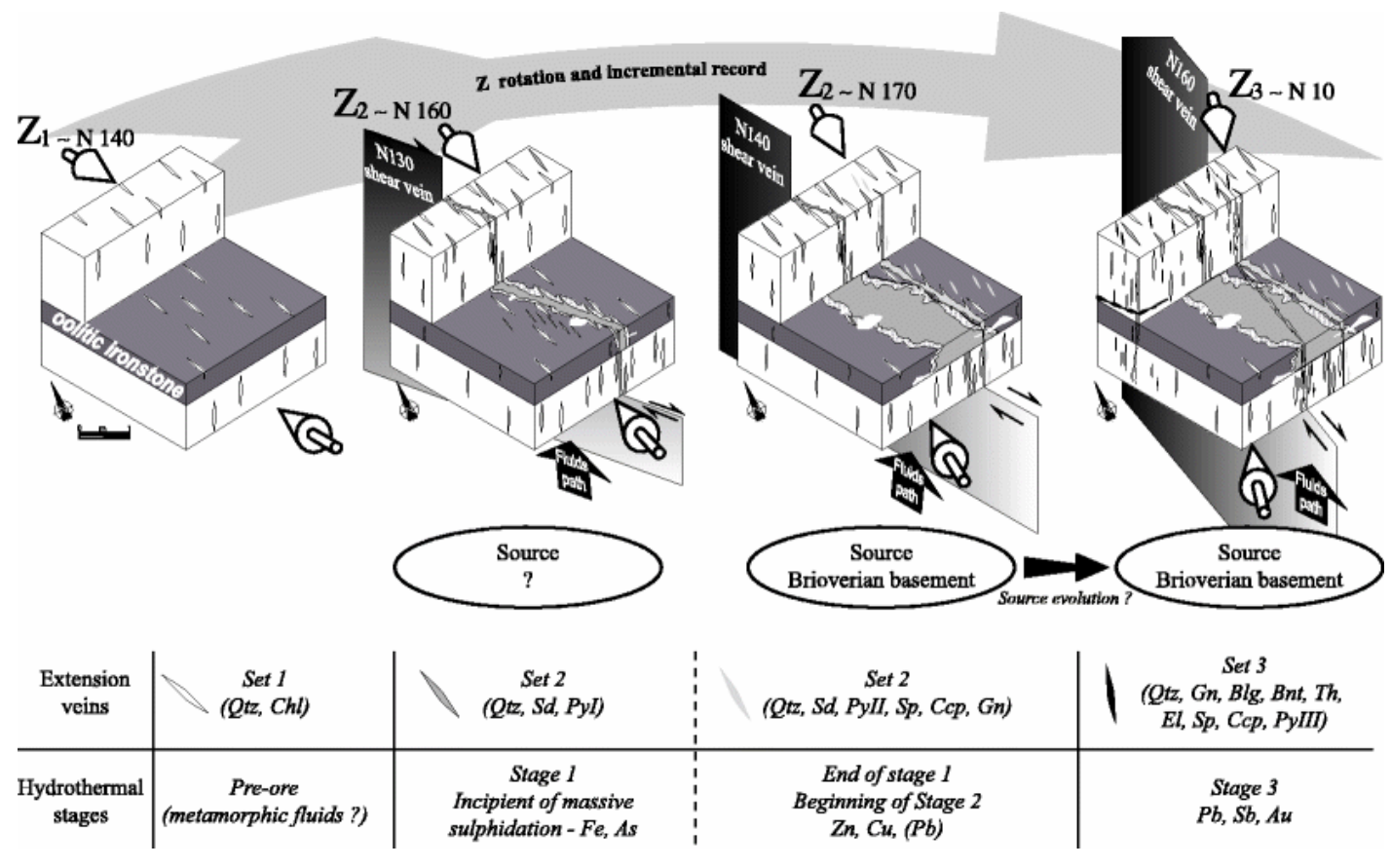

Fig. 11 Fluid flow model of mineralization for Saint-Aubin-des-Châteaux mineralization related to three incremental steps of deformation (see text for explanation)

The second increment of deformation corresponds to a broad $\mathrm{N} 160^{\circ} \mathrm{E}$ shortening direction (Z2). The massive sulphidation stage (stage 1) and the polymetallic stage (stage 2) developed during this episode. SE-trending dextral faults, shear veins and associated tension gashes (set 2) also formed during this increment. In these structures, hydrothermal infill shows a progressive evolution from stage 1 to stage 2 paragenesis attesting (1) the continuum of deformation and (2) the evolution of fluid composition. Fluids originated from the underlying Neo-Proterozoic basement. They were channelised along sub-vertical dextral faults and induced extensive massive sulphidation of $\mathrm{OIH}$ (stage 1). Subsequent fracturing affecting $\mathrm{OIH}$ and massive sulphide lenses led to the deposition of stage 2 paragenesis. Within $\mathrm{OIH}$, this stage 2 also induces a restricted replacive sulphidation, along the vein walls.

The third increment corresponds to a $\mathrm{N} 10^{\circ} \mathrm{E}$ shortening direction (Z3) during which SSEtrending shear veins and associated tension gashes (set 3) developed. These structures are filled with stage 3 paragenesis including gold deposition. Like previous hydrothermal stages, stage 3 triggered a restricted replacive sulphidation within OIH vein walls. Faults and shear veins continued to be the major drains of fluids. Lead isotopes suggest that these fluids still record a Neo-Proterozoic basement signature.

\section{Discussion}

This model of successive incremental deformations steps and fluid input is consistent with the clockwise rotation of strain axes during the bulk dextral simple shear undergone by the CAD during the Carboniferous. In an outcrop located $30 \mathrm{~km}$ westwards of the Saint-Aubin-desChâteaux quarry, Choukroune et al. (1983) demonstrated the same local clockwise rotation of similar incremental shortening axes. These authors based their analysis on crosscutting relations between several generations of tension gashes, strike-slip faults, folds and associated cleavage. We have shown that the incremental rotation of strain axis during simple shear is 
also recorded by distinct hydrothermal infill of fractures from pre-ore quartz to $\mathrm{a} \mathrm{Pb}-\mathrm{Sb}-\mathrm{Au}$ stage (stage 3). This has important consequences for dating successive increments of deformation and duration of hydrothermal systems. Gumiaux et al. (2004) used geostatistical restoration of deformation at the CAD-scale and established the clockwise rotation of the shortening axis from $\mathrm{N} 160^{\circ} \mathrm{E}$ at $355-345 \mathrm{Ma}$ to $\mathrm{N} 10^{\circ} \mathrm{E}$ at $310-300 \mathrm{Ma}$. By analogy, we suggest that, at Saint-Aubin-des-Châteaux, (1) the hydrothermal activity (three successive fluid pulses) was recorded by stages 1 to 3 and was active during the 345-310 Ma time span and (2) the pre-ore quartz dominant stage developed before $345 \mathrm{Ma}$. This model has some uncertainty because local and regional deformations are not scale-invariant, due to a heterogeneous strain gradient. However, we argue that massive sulphidation (stage 1) and the $\mathrm{Cu}-\mathrm{Zn}$ polymetallic stage 2 was not related to the so-called Late Hercynian or "Late Variscan" mineralisations (e.g. Chauris and Marcoux 1994; Bouchot et al. 2000), consistent with the lead isotope characteristics, which show a shift from the domain of Late Hercynian deposits (low-temperature field, Fig. 10). There are no radiometric age data available for the mineralising events within the Armorican Massif. Following our structural, petrological and geochemical data, we propose that many base metal vein-type deposits may have formed during Carboniferous times, before $310 \mathrm{Ma}$.

The late $\mathrm{Pb}-\mathrm{Sb}-\mathrm{Au}$ mineralisation (stage 3 ) of the Saint-Aubin-des-Châteaux quarry appears to be compatible with a $\mathrm{N} 10^{\circ} \mathrm{E}$ shortening direction (Z3 in Fig. 11). Within the Hercynian Armorican Massif, this direction corresponds to a Late Hercynian event during a 310-300 Ma time span (Gumiaux et al. 2004). According to Bouchot et al. (2000, 2005), this time span marks a peak of metalliferous activity, and particularly for $\mathrm{Au} \pm \mathrm{Sb}$, in the Hercynian French Massif Central. Moreover, the sulphide/sulphosalt paragenetic evolution observed in the Saint-Aubin-des-Châteaux quarry is very similar to that described for orogenic $\mathrm{Au} \pm \mathrm{Sb}$ deposits of the French Massif Central (Bouchot et al. 2005). Thus, we can suggest that both the Armorican and Massif Central areas underwent a similar peak of orogenic $\mathrm{Au} \pm \mathrm{Sb}$ deposition at 310-300 Ma. More geochronological, isotopic and fluid inclusion studies would be useful to validate the model proposed for the Saint-Aubin-des-Châteaux ores and to assess the metallogenic context of the Armorican mineralisation.

The lack of W- and Sn-bearing minerals in the Saint-Aubin-des-Châteaux ores argues also for an orogenic mineralisation type as defined by Bouchot et al. (2005), and against a magmatichydrothermal affiliation. Granite-related Sn-W deposits are common along the NBSASZ east and west of Saint-Aubin-des-Châteaux (Fig. 1b). However, no outcropping or sub-surface granite has been recognised by gravity data between La Gacilly and Angers along the NBSASZ (Fig. 1b, Vigneresse 1983). Thus, the Hercynian orogenic type seems to be the most suitable deposit class for the Saint-Aubin-des-Châteaux epigenetic mineralisation. Following Bouchot et al. (2005), the brittle structural control during the mineralising event argues for a shallow emplacement level of the gold deposition. This is in accordance with the shallow depth reached by the Grès armoricain Formation in this area during the Hercynian orogeny. Our data from both chlorite and arsenopyrite geothermometers agree with a hot hydrothermal fluid (maximum temperature ranging from $350-390^{\circ} \mathrm{C}$ ) during massive sulphidation (stage 1). This probably implies that fluids were not in thermal equilibrium with their host rocks. It is noteworthy that many chloritoid aureoles have been mapped and interpreted as being the result of hidden granite intrusions in the studied area (Le Corre 1969; Lopez-Munoz 1981). We suggest that, rather than sub-surface granites, the input of hot hydrothermal fluids was responsible for local thermal anomalies triggering chloritoid growth. Chloritoid growth has been reported in other non-granite-related hydrothermal systems in basins (Branquet 1999; Branquet et al. 1999). 
All the data presented in this study demonstrate the epigenetic character of the Saint-Aubindes-Châteaux sulphide mineralisation. Remobilisation of syngenetic pre-concentration of metals such as $\mathrm{As}, \mathrm{Sb}, \mathrm{Cu}, \mathrm{Pb}$ and $\mathrm{Zn}$ (and probably $\mathrm{Au}$ ) within $\mathrm{OIH}$ are neither compatible with bulk-rock non-altered ironstone compositions (Fig. 7 and Table 1) nor with lead isotope characteristics (Fig. 10 and Table 5). The metals were derived from other sources than $\mathrm{OIH}$ and surrounding sandstones, where these elements are at very low concentration (Dabard 1983). They were transported by hydrothermal fluids along faults through the Ordovician sedimentary formations. The influx of fluids through $\mathrm{OIH}$ induced remobilisation of sedimentary and diagenetic pre-concentrations of $\mathrm{P}, \mathrm{Sr}, \mathrm{V}, \mathrm{Sc}$ and $\mathrm{Co}$ within $\mathrm{OIH}$. This is coherent with positive anomalies in $\mathrm{Sr}, \mathrm{V}$ and $\mathrm{P}$ recorded in all Armorican Palaeozoic formations (Dabard 1983), which are linked to physico-chemical conditions of the sedimentary environment and especially to the presence of organic matter. Thus, these sedimentary pre-concentrations led to the development of a spectacular hydrothermal paragenesis including rare Sc- and Sr-bearing phosphates and many apatite generations (Moëlo et al. 2000, 2002).

The epigenetic massive sulphide lenses formed during stage 1 within the oolitic ironstone are very similar to the Au-bearing sulphide halos described in BIF-hosted gold deposits (Phillips et al. 1984; Thompson et al. 1990; Ledru and Bouchot 1993). In these latter deposits, gold is found in sulphide halos or lenses that developed when mineralising fractures intersect the BIF (Thompson et al. 1990). Sulphide replacement and hydrothermal halos are important in oxide layers, whereas they are minimal in the chert layers of BIF. Thus, like BIF-hosted gold deposits, the oolitic ironstone from Saint-Aubin-des-Châteaux behaved as a lateral chemical trap for epigenetic fluid circulating in vertical fractures and faults.

\section{Implications for mineral exploration}

The Saint-Aubin-des-Châteaux quarry is the first recognition of an epigenetic imprint on a Palaeozoic oolitic ironstone. This exceptional example results from the conjunction of three main factors, which are (1) the chemical reactivity of the carbonate-rich ironstone with acid hydrothermal fluids, (2) the deformation of the whole Palaeozoic sequence, expressed as a network of strike-slip faults that acted as conduits and (3) the vicinity of the Hercynian internal domain, which provided hydrothermal fluids by metamorphism. Palaeozoic ironstones are present on a large scale in the western European Hercynian belt, linked to the border zone of the Gondwanian Craton and peri-Gondwanian microplates. Some are found in NW France, NW Spain and Portugal, NE Italy and Sardinia, Morocco and Libya (detailed review in Van Houten and Arthur 1989; Van Houten and Hong-Fei 1990). In these places, ironstones present many similar mineralogical and chemical features to the Armorican occurrences (see, for example, the comparative study of Fernández et al. 1998; Fernández and Moro 1998; Franceschelli et al. 2000). They are also frequently deformed close to the Hercynian internal domain. Thus, despite the exploration difficulties to localise massive sulphidation areas within ironstones, as massive sulphide lenses intercalated within the thick Grès armoricain Formation are difficult to detect by geophysical surveys, these areas represent potential targets for gold and base-metal exploration.

\section{Conclusion}

At Saint-Aubin-des-Châteaux, Hercynian Armorican Massif, France, the oolitic ironstone hosted within Ordovician sandstones (Grès armoricain Formation) underwent strong epigenetic hydrothermal overprint responsible for pervasive and massive sulphidation, followed by the deposition of a Au-bearing polymetallic paragenesis. To our knowledge, this is the first clearly identified occurrence worldwide of extensive hydrothermal alteration 
affecting a siderite-chamosite-type oolitic ironstone. The mineralisation is structurally controlled by strike-slip faulting induced by the bulk right-lateral simple shear affecting the CAD during the Hercynian orogeny. Faults are clearly identified as major drains for parent fluids. Simple shear increments are recorded by at least three sets of compatible fractures filled with distinct hydrothermal assemblages. Structural data and lead isotope characteristics of galena argue for an Hercynian syn-orogenic age (before $310 \mathrm{Ma}$ ) for the first main stage of the mineralisation, which consists of massive sulphidation. A "classical" Late Hercynian orogenic age (310-300 Ma) appears to be compatible for the last sulphosalt-gold-bearing stage. Absolute ages of ore formation are still lacking in the French Armorican Massif and would be important to further understanding of the metallogenic history of the Hercynian belt.

With the exception of faults, the hydrothermal alteration, and particularly lateral massive sulphidation, is restricted to oolitic ironstone rather than enclosing sandstone. Thus, oolitic ironstone can behave as a chemical trap for mineralising fluids. In that sense, replacive massive sulphidation and subsequent Au-bearing mineralisation within oolitic ironstones show exactly similar chemical and structural controls to those of epigenetic Archaean/Proterozoic BIF-hosted gold deposits. This suggests that sulphidation of a sideritechamosite oolitic ironstone might be as important for gold ore formation as in the betterknown BIF variant of iron formations.

The orogenic context is an important key factor controlling this mineralising process, and has important consequences for metal exploration within deformed sedimentary sequences hosting ironstones. In the Hercynian belt, several segments as Galicia and Sardinia present Ordovician oolitic ironstones (e.g. Fernández et al. 1998; Franceschelli et al. 2000). These could have behaved as similar structural and chemical trap for mineralising fluids to those described in the Saint-Aubin-des-Châteaux area.

Acknowledgement The authors thank Dr. J.-P. Pierres, B. Geibig (geologists of Hervé S.A. Compagny) and all the personnel of the Saint-Aubin-des-Châteaux quarry for support during field work and sampling. The technical assistance of N. Morin and J.-J. Peucat (Rennes1 University) for lead isotope analysis and O. Rouer (ISTO) for EPMA is greatly appreciated. Geochemical data from Table 1 and Fig. 7 have been obtained within the framework of the PATRIFER program. We are grateful to V. Bouchot (BRGM) who has greatly contributed to improve this manuscript with advice and bibliographic inputs. Thanks also to Dr. J.-P. Lorand and Pr. M. Guiraud (MNHN Paris) for fruitful discussions. The manuscript was greatly improved by critical reviews and language revision by J. Miller (University of Melbourne, Australia), an anonymous French reviewer, and B. Lehmann.

This paper is dedicated in memory to Pr. Jean-Jacques Chauvel who suddenly died during the preparation of this paper.

\section{References}

Almeida A, Noronha F (1988) Fluid associated with $\mathrm{W}$ and $\mathrm{Au}-\mathrm{Ag}$ deposits of the Mirandela area, NE Portugal: an example of peri-granitic zoning. Bull Minéral 111:331-341

Angelier J, Mechler P (1977) Sur la méthode graphique de recherche des contraintes principales également utilisable en tectonique et en séismologie: la méthode des dièdres droits. Bull Soc Géol Fr 7, t. XIX, 6:1309-1318 
Bailey SW (1980) Summary of recommendations of AIPEA nomenclature committee. Clays Clay Miner 28:73-78

Bellanger E (1911) Note sur l'importance probable du gisement ferrifère de l'Anjou. An Mines 20:452-456

Berthé D, Choukroune P, Jégouzo P (1979) Orthogneiss, mylonite and non-coaxial deformation of granites: the example of the South Armorican Shear Zone. J Struct Geol 1:3142

Bouchot V, Milési JP, Ledru P (2000) Crustal-scale hydrothermal palaeofield and related Variscan $\mathrm{Au}, \mathrm{Sb}, \mathrm{W}$ orogenic deposits at 310-305 Ma (French Massif Central, Variscan belt). SGA News 10:6-12

Bouchot V, Ledru P, Lerouge C, Lescuyer J-L, Milesi J-P (2005) 5: Late Variscan mineralizing systems related to orogenic processes: the French Massif Central. Ore Geol Rev 27:169-197

Branquet Y (1999) Etude structurale et métallogénique des gisements d'émeraude de Colombie: contribution à l'histoire tectono-sédimentaire de la Cordillère Orientale de Colombie Institut National Polytechnique de Lorraine, Nancy. Thesis, 295 p

Branquet Y, Laumonier B, Cheilletz A, Giuliani G (1999) Emeralds in the eastern Cordillera of Colombia: two tectonic settings for one mineralization. Geology 27:597-600

Bril H (1982) Les minéralisations plombo-zincifères du second cycle dans le district de Brioude-Massiac (Massif central français): données géochimiques et isotopiques. Bull BRGM (2), section II:225-235

Bril H (1985) Conditions de stabilité des sulfures dans les filons de haute température du district de Brioude-Massiac (Massif central français). Bull Minéral 108:161-171

Bril H, Fouquet Y, Moëlo Y, Picot P (1981) Utilisation du mispickel comme indicateur géochimique en métallogénie régionale In: B.R.G.M. (ed) Résumés des principaux résultats scientifiques et techniques du S.G.N. pour 1980. Orléans, pp 84-86

Carron J-P, Le Guen de Kerneizon M, Nachit H (1994) Variscan granites from Brittany. In: Keppie JD (ed) Pre-Mesozoic geology in France and related areas. Springer, Berlin Heidelberg New York, pp 231-239

Cartier C (2002) Structure de l'unité de Saint-Georges-Sur-Loire et du domaine ligérien (Massif Armoricain). Implications géodynamiques pour la Chaîne hercynienne. Thesis, Université d'Orléans, 309 p : http://tel.archives-ouvertes.fr/tel-00001926

Cathelineau M (1988) Cation site occupancy in chlorites and illites as a function of temperature. Clay Miner 23:471-485

Cathelineau M, Nieva D (1985) A chlorite solid solution geothermometer. The Los Azufres (Mexico) geothermal system. Contrib Mineral Petrol 91:235-244 
Chantraine J, Autran A, Cavelier C (1996) Carte géologique de la France. BRGM, Orléans

Chauris L, Marcoux E (1994) Metallogeny of Armorican Massif. In: Keppie JD (ed) PreMesozoic geology in France and related area. Springer, Berlin Heidelberg New York, pp 243264

Chauris L, Houlgatte E, Laforet C, Picot P (1985) Un district antimono-aurifère à gangue quartzo-carbonatée, Le Semnon (Ille-et-Vilaine, Massif Armoricain, France). Hercynica I:111-119

Chauvel J-J (1971) Contribution à l'étude des minerais de fer de l'Ordovicien inférieur de Bretagne. Mém Soc Géol Minér Bretagne 16:244

Chauvel JJ (1974) Les minerais de fer de l'Ordovicien inférieur du bassin de Bretagne-Anjou, France. Sedimentology 21:127-147

Chauvel J-J, Le Corre C (1971) La transgression paléozoïque et l'Ordovicien inférieur dans la presqu'île de Crozon (Finistère) Mém. BRGM, Orléans, pp 109-117

Chauvel JJ, Phan KD (1965) Présence d'apatite strontianifère dans le minerai de fer de l'Ordovicien inférieur de Bretagne. C R Acad Sci Paris 260:2855-2857

Choukroune P, Lopez-Munoz M, Ouali J (1983) Cisaillement ductile sud-armoricain et déformations discontinues associées: mise en évidence de la déformation régionale non coaxiale dextre. C R Acad Sci Paris 296:657-660

Christie T, Brathwaite B (1997) Mineral commodity report 15-Iron. NZ Min 22:22-37

Cotter E, Link JE (1993) Deposition and diagenesis of Clinton ironstones (Silurian) in the Appalachian Foreland Basin of Pennsylvania. Geol Soc Amer Bull 105:911-922

Cumming GL, Richards JR (1975) Ore lead isotope ratios in a continuously changing Earth. Earth Planet Sci Lett 28:155-171

Dabard M-P (1983) Etude pétrographique et géochimique des roches sédimentaires paléozoïques du Massif Armoricain-Presqu'île de Crozon, Flanc Nord du bassin de laval. Thesis, Université de Rennes I, 207 p

Dadet P, Herrouin Y, Laville P, Paris F (1987) Carte géologique de la France-Bain-deBretagne (388). BRGM, Orléans

Davy L (1880) Notice géologique sur l'arrondissement de Segré. Bull Soc Ind Minér 9:1-101

Donnot M, Guigues J, Lulzac Y, Magnien A, Parfenoff A, Picot P (1973) Un nouveau type de gisement d'europium: la monazite grise à europium en nodules dans les schistes paléozoïques de Bretagne. Miner Depos 8:7-18

Dubreuil M, Blaise J, Cavet P, Diot H, Gruet M (1988) Carte géologique de la France-SaintMars-la-Jaille (421). BRGM, Orléans 
Durand J, Noblet C (1986) Paléocourants dans la Formation du Grès armoricain: persistance des mécanismes de transport en domaine cratonique. Rev Géol Dyn Géogr Phys 27:13-26

Fernández A, Moro MC (1998) Origin and depositional environment of Ordovician stratiform iron mineralization from Zamora (NW Iberian peninsula). Miner Depos 33:606-619

Fernández A, Chauvel J-J, Moro MC (1998) Comparative study of the Lower Ordovician ironstones of the Iberian massif (Zamora, Spain) and of the Armorican Massif (Central Brittany, France). J Sediment Res 68:53-62

Foster RP, Gilligan JM (1987) Archaean iron-formation and gold mineralization in Zimbabwe. In: Uitterdijk Appel PW, Laberge GL (eds) Precambrian iron formations. Theophrastus Publication, S. A., Athens, Greece, pp 635-674

Franceschelli M, Puxeddu M, Carta M (2000) Mineralogy and geochemistry of late Ordovician phosphate-bearing oolitic ironstones from NW Sardinia, Italy. Mineral Petrol 69:267-293

Fripp REP (1976) Stratabound gold deposits in Archean banded iron-formation, Rhodesia. Econ Geol 71:58-75

Gapais D, Le Corre C (1980) Is the Hercynian belt of Brittany a major shear zone? Nature 288:574-576

Gloaguen E (2002) Etude structurale et métallogénique du minerai de fer hydrothermalisé de la carrière de Saint-Aubin-Des-Châteaux, Loire-Atlantique (France). Master research report, Université d'Orléans, $41 \mathrm{p}$

Gross GA (1996a) Gîtes stratiformes de fer In: Eckstrand OR, Sinclair WD, Thorpe RI (eds) Géologie des types de gîtes minéraux du Canada. Comm Géol Can 8:47-90

Gross GA (1996b) Roches ferrugineuses In: Eckstrand OR, Sinclair WD, Thorpe RI (eds) Géologie des types de gîtes minéraux du Canada. Comm Géol Can, pp 82-90

Groves DI, Vearcombes JR (1990) The scale of ore-depositional system: an important restraint on epigenic vs remobilised syngenetic origins for Archean mesothermal gold deposits. Geol Rundsch 79:345-353

Guillocheau F, Rolet M (1982) La sédimentation Paléozoïque Ouest-Armoricaine. Bull Soc Géol Minéral Bretagne 14(2):45-62

Gumiaux C (2003) Modélisation du cisaillement de Bretagne Centrale: déformation crustale et implications lithosphériques. Mém Geosci Rennes 106:266

Gumiaux C, Gapais D, Brun JP, Chantraine J, Ruffet G (2004) Tectonic history of the Hercynian Armorican Shear belt (Brittany, France). Geodin Acta 17:289-307

Herrouin Y, Rabu D, Fourniguet J (1988) Carte géologique de la France-Châteaubriant (389). BRGM, Orléans 
Herrouin Y, Dadet P, Guigues J, Laville P, Talbo H (1989) Notice explicative, carte géologique de la France (1/50 000), Bain-de-Bretagne (388). BRGM, Orléans, pp 82

Hillier S, Velde B (1991) Octahedral occupancy and the chemical composition of diagenetic (low-temperature) chlorites. Clay Miner 26:149-168

Jégouzo P (1980) The South Armoricain Shear Zone. J Struct Geol 2(1-2):39-47

Joseph P (1982) Le minerai de fer oolithique ordovicien du Massif Armoricain: Sédimentologie et Paléogéographie Ecole Nationale Supérieure des Mines de Paris. Thesis, $324 \mathrm{p}$

Jowett EC (1991) Fitting iron and magnesium into the hydrothermal chlorite geothermometer. In: GAC/MAC/SEG Joint Annual Meeting, Toronto, May 27-29, 1991, 16, A62, Program with Abstracts

Kerforne F (1914) Sur la position systématique des couches de minerai de fer de l'Ordovicien inférieur de la région de Châteaubriant. C R hebd Séanc Acad Sci Paris 159:758-760

Kerforne F (1915) Etude géologique de la région silurienne de Châteaubriant (LoireInférieure). Bull Soc Géol Fr 3(15):191

Kerforne F (1923) Les gisements minéralisés de La Chapelle-Saint-Melaine (I. et V.). Bull Soc Géol Minéral Bretagne 3:23

Kerrich R, Fryer BJ (1979) Archaean precious metal hydrothermal systems, Dome mine, Abitibi Greenstone belt. II. REE and oxygen isotope relations. Can J Earth Sci 16:440-458

Kranidiotis P, MacLean WH (1987) Systematics of chlorite alteration at the Phelps Dodge massive sulfide deposit, Matagami, Quebec. Econ Geol 82:1898-1911

Kretschmar U, Scott SD (1976) Phase relations involving arsenopyrite in the system Fe-As-S and their application. Can Miner 14:364-386

Le Corre C (1969) Sur une paragenèse à chloritoïde dans les schistes de l'Ordovicien moyen des synclinaux du Sud de Rennes (Massif Armoricain). Bull Soc Géol Minéral Bretagne (C):33-44

Le Corre C (1975) Analyse comparée de la cristallinité des micas dans le Briovérien et le Paléozoïque Centre-Armoricains: zonéographie et structure d'un domaine épizonal. Bull Soc Géol Fr XVII:8

Le Corre C (1978) Approche quantitative des processus synschisteux. L'exemple du segment Hercynien de Bretagne Centrale. Thesis, Université de Rennes I, 382 p

Le Corre C, Auvray B, Ballèvre M, Robardet M (1991) Le Massif Armoricain. Sci Geol Bull 44(1-2):31-103 
Ledru P, Bouchot V (1993) Revue des minéralisations aurifères de Craton Précambrien de São Francisco (Brésil) et discussion sur leurs contrôles structuraux. Chron Rech Min 511:520

Lopez-Munoz M (1981) Analyse structurale de la partie centrale du synclinorium de SaintJulien-de-Vouvantes et de l'axe Lanvaux-Les-Ponts-de-Cé (Massif Armoricain). Bull Soc Géol Minéral Bretagne XIII:117-123

Lyons JC (ed) (1957) Wabana iron ore deposits. The Canadian Institute of Mining and Metallurgy, Montreal, Quebec

Macdonald AJ (ed) (1990) Banded oxide facies iron formation as a host for gold mineralization. Theophrastus Publications, S. A., Athens, Greece

Marcoux E (1987) Isotopes du plomb et paragenèses métalliques, traceurs de l'histoire des gîtes minéraux. Doc BRGM 117, Orléans

Maurel Palacin D (1985) Etude des filons polymétalliques (W, Au, Ag.) au Sud de Mirandela (Trás-os-Montes, Portugal). Relations avec les granites Université Pierre \& Marie Curie (Paris VI). Mém Sci Terre 85-01, 214 p

McCuaig CT, Kerrich R (1998) $P-T-t$-deformation-fluid characteristics of lode gold deposits: evidence from alteration systematics. Ore Geol Rev 12:381-453

McDowell SD, Elders WA (1980) Authigenic layer silicate minerals in borehole Elmore 1, Salton Sea geothermal field, California, USA. Contrib Mineral Petrol 74:293-310

Méloux J, Rouveyrol P, Guigues J, Dumas J, Durand G, Gorichon A, Le Fur Y, Lemarchand R, Mulot B (1979) Carte des gîtes minéraux de la France-Nantes. BRGM, Orléans

Moëlo Y, Ohnenstetter D, Marcoux E, Maurel D (1985) Etude méthodologique relative à la non-stoechiométrie du mispickel, $\mathrm{FeAs}_{1-\mathrm{x}} \mathrm{S}_{1+\mathrm{x}}$. Résumés des principaux résultats scientifiques et techniques du BRGM pour 1984:303

Moëlo Y, Lasnier B, Palvadeau P, Léone P, Fontan F (2000) La Lulzacite, $\mathrm{Sr}_{2} \mathrm{Fe}^{2+}\left(\mathrm{Fe}^{2+}, \mathrm{Mg}\right)_{2} \mathrm{Al}_{4}(\mathrm{PO} 4)_{4}(\mathrm{OH})_{10}$, un nouveau phosphate de strontium (Saint-Aubin-DesChateâux, Loire-Atlantique, France). C R Acad Sci Paris 330:314-324

Moëlo Y, Lulzac Y, Rouer O, Palvadeau P, Gloaguen E, Léone P (2002) Scandium mineralogy: pretulite with scandian zircon and xenotime-(Y) within an apatite-rich oolitic ironstone from Saint-Aubin-Des-Châteaux, Armorican Massif, France. Can Miner 40:16571673

Newton PGN, Ridley JR, Groves DI, Khosrowshahi S, Smith B (1997) Integration of directional variography and structural geology: an example from the Santa Craze BIF-hosted Au deposit, near Kalgoorlie, Western Australia. Chron Rech Min 529:105-125

Noblet C (1983) Interprétations des cartes d'isopaques de la Formation du Grès armoricain levées en Bretagne et en Normandie. Géol Fr 2:311-320 
Oh M-S, Marcoux E, Calvez J-Y, Touray J-C (1989) Anomalous unradiogenic lead from strata-bound $\mathrm{Zn}-\mathrm{Pb}-\mathrm{Cu}$ mineralization in the Saint-Georges-sur-Loire synclinorium (Armorican Massif, France). Econ Geol 84:1436-1443

Phillips GN, Groves DI, Martyn JE (1984) An epigenetic origin for Archean banded ironformation-hosted gold deposits. Econ Geol 79:162-171

Puzenat L (1939) La sidérurgie armoricaine. Mém Soc Géol Minér Bretagne IV:399

Roman-Berdiel T, Gapais D, Brun JP (1997) Granite intrusion along strike-slip zones in experiment an nature. Am J Sci 297:651-678

Sharp ZD, Essene EJ, Kelly WC (1985) A re-examination of the arsenopyrite geothermometer: pressure considerations and applications to natural assemblages. Can Miner 23:517-534

Sibson RH (1990) Faulting and fluid flow In: Nesbitt BE (ed) Short course on fluids in tectonically active regime of the continental crust. Mineral Assoc Canada, Vancouver, May 1990, pp 93-132

Spears DA (1989) Aspects of iron incorporation into sediments with special reference to the Yorkshire Ironstone. In: Young TP, Taylor WEG (eds) Phanerozoic ironstones. Geological Society Special Paper, London, pp 19-30

Spears DA, Caswell SA (1986) Mineral matter in coals: cleat minerals and their origin in some coals from the English midlands. Int J Coal Geol 6:107-125

Stacey JS, Kramers JD (1975) Approximation of terrestrial lead isotope evolution by a two stage model. Earth Planet Sci Lett 26:207-221

Sundblad K, Zachrisson E, Smeds SA, Berglund S, Aalinder C (1984) Sphalerite geobarometry and arsenopyrite geothermometry applied to metamorphosed sulfide ores in the Swedish Caledonides. Econ Geol 79:1660-1668

Thompson MJ, Watchorn RB, Bonwick CM, Frewin MO, Goodgame VR, Pyle MJ, MacGeehan PJ (eds) (1990) Gold deposits of Hill 50 Gold Mine NL at Mount Magnet. The Australasian Institute of Mining and Metallurgy, Melbourne

Trautmann F, Donnot M, Lemaire D, Cagnet-Mawhin MP (1987) Carte géologique de la France-Nozay (420). BRGM, Orléans

Van Houten FB, Arthur MA (1989) Temporal patterns among Phanerozoic oolitic ironstones and oceanic anoxia. In: Young TP, Taylor WEG (eds) Phanerozoic ironstones. Geological Society Special Publication, pp 33-39

Van Houten FB, Hong-Fei H (1990) Stratigraphic and palaeogeographic distribution of Palaeozoic oolitic ironstones. In: McKerrow WS, Scotese CR (eds) Palaeozoic palaeogeography and biogeography. Geol Soc Mem 12:87-93 
Vigneresse J-L (1983) Enracinement des granites armoricains estimés d'après la gravimétrie. Bull Soc Géol Minéral Bretagne 15:1-15

Vigneresse JL, Brun JP (1983) Les leucogranites armoricains. Structures et mise en place des granites hercyniens. Bull Soc Géol Fr 25(3):357-366

Walshe JL (1986) A six-component chlorite solid solution model and the conditions of chlorite formation in hydrothermal and geothermal systems. Econ Geol 81:681-703

Xie X, Byerly GR, Ferrel REJ (1997) IIb Trioctahedral chlorite from the Barberton Greenstone belt: crystal structure and rock composition constraints with implications to geothermometry. Contrib Mineral Petrol 126:275-291

Zang W, Fyfe WS (1995) Chloritization of the hydrothermally altered bedrock at the Igarapé Bahia gold deposit, Carajas, Brazil. Miner Depos 30:30-38 